\title{
Kolektif Hafıza Bağlamında Fransız Dili ve Kültürünün Gazi Mustafa Kemal Atatürk'ün Entelektüel ve Devrimci Kişiliğinin Oluşumuna Etkisi
}

\author{
DR. ÖĞR. ÜYESİ PINAR SEZGINTTÜRK*
}

\section{Öz}

Fransız Dilinin yıllarca Türklerin dış dünyayı keşfetmelerine olanak sağlayan bir araç olduğu yadsınamaz bir gerçektir. Fransız aydınlarının düşünceleri, XIX. yüzyılın ortasından itibaren Türkiye'de ortaya çıkan çeşitli devrimci hareketlere önemli bir esin kaynağı olmuştur. Türkler, Fransızca kaynaklar ve Fransız basın aracılığıyla dönemin büyük problemlerinden haberdar olmanın yanı sıra Anadolu'ya gelip kendi gözlem ve deneyimlerini kaleme alan Fransızlar sayesinde kendilerini Batı dünyasına tanıtma imkânı bulmuştur. Fransız Diline oldukça hâkim Jön Türklerin (Jeunes Turcs) çağdaşlaşma mücadeleleri ve en önemlisi de bağımsız ve çağdaş bir Türkiye için yola koyulan Ulu Önderimiz Mustafa Kemal Atatürk'ün gerçekleştireceği önemli devrimlerin temel taşları Fransızca kaynaklardan edinilen bilgiler ışığında olmuştur. Gerek Fransız aydınlar tarafından kaleme alınmış yapıtlar, gerekse de Fransa'ya gerçekleştirdiği yolculuk ve Fransızlarla olan yakın ilişkisi sayesinde edindiği kazanımların Atatürk'ün entelektüel ve devrimci kişiliğinin oluşumuna etkisi bu makalenin ana konusunu oluşturmaktadır. Bunun yanında, Millî Mücadele döneminde bizzat ülkemize gelip Yeni Türkiye'nin verdiği Diriliş Mücadelesine ve gerçekleştirilen sosyal, siyasal, moral ve ekonomik tüm devrimlere tanıklık eden, kendi gözlem, inceleme ve araştırmalarına dayanarak kaleme aldığı yapıtlarla, Batı'da sesimizi duyuran çok sayıda Türk dostu Fransız devlet adamı, tarihçi, yazar ve gazeteci vardır.

$\mathrm{Bu}$ çalışmada, Mustafa Kemal Atatürk tarafından titizlikle okunan Fransız yazarların yapıtları ile Millî Mücadele ve Cumhuriyet Dönemine tanıklık etmiş Fransızların gözünden Yeni Türkiye konulu yapıtlar, kolektif hafıza bağlamında incelenerek tarihimizin en sancılı dönemi ile ilgili kolektif hafızanın korunmasına ve kuşaklar boyunca aktarılmasına katkı sağlamayı amaçlanmaktadır.

Anahtar sözcükler: Mustafa Kemal Atatürk, Yeni Türkiye, Fransa, Fransız Dili ve Kültürü, Millî Mücadele ve Cumhuriyet Dönemi, Kolektif Hafıza

THE EFFECT OF THE FRENCH LANGUAGE AND CULTURE ON THE FORMATION OF MUSTAFA KEMAL ATATÜRK'S INTELLECTUAL AND REVOLUTIONARY PERSONALITY: IN THE CONTEXT OF COLLECTIVE MEMORY

\section{Abstract}

It is an undeniable fact that the French language has been a tool for years that allows Turks to discover the outside world. The ideas of French intellects serve as an important source of

\footnotetext{
* Çanakkale 18 Mart Ün. YD Yüksekokulu, psezginturk@comu.edu.tr, orcid: 0000-0002-6820-7150 
inspiration for various revolutionary movements that emerged in Turkey from the middle of the 19th century. Turks were aware of the major problems of the era through French resources and the French press and found the opportunity to introduce themselves to the Western world thanks to the French who came to Anatolia and wrote their own observations and experiences. The modernization struggles of members of the Young Turks (Jeunes Turcs) who were quite adept at the French language, and, more importantly, the foundation for important revolutions carried out by our national leader Mustafa Kemal Ataturk, who set out for an independent and modern Turkey, arose in light of the information procured from French resources. The effect of the gains Ataturk acquired thanks to both the works penned by French intellectuals and the journey he made to France and his close relationship with the French on the formation of his intellectual and revolutionary personality constitutes the main subject of this article. In addition to this there are numerous French statesmen, historians, writers, and journalists who are friends of the Turks who cam to our country during the National Struggle period, who witnessed the Revival Struggle that the New Turkey gave and all the social, political, moral, and economic revolutions that took place, and who made their voices heard in the West with the works they wrote based on their own observations, investigations, and research.

The purpose of this article is to present and to study in the context of collective memory the works by French writers that Ataturk so meticulously studied and the works regarding the New Turkey from the perspective of the French who witness the National Struggle and the Republican Era in terms of contributing to the preservation and transfer to future generations of the collective memory regarding the most painful period of our history.

Keywords: Mustafa Kemal Atatürk, New Turkey, France, French Language and Literature, the National Struggle and the Republican Era, Collective Memory

\section{GİISŞ}

Tip, hukuk, sanat, askerî bilimler ve sosyoloji alanlarında Türkiye'ye yol gösteren dil her zaman Fransızca olmuş; bunun en güzel örneğini de kuşkusuz bağımsızlık ve uygarlık mücadelesinde her zaman Fransızca kaynaklara başvuran Mustafa Kemal Atatürk gösterir. Okul sıralarından itibaren bitmek bilmeyen bilgi açlığıyla yazınsal yapıtlardan siyasi-politik ve felsefi yapıtlara kadar çoğu Fransız yazarlar tarafından kaleme alınan yapıtları saatlerce okuyan, önemli gördükleri satırların altını çizen, etrafına notlar düşen Mustafa Kemal Atatürk için Fransız dili dış dünyaya açılan bir pencere olmuştur. Askerlik, hukuk, tarih, felsefe ve edebiyat alanlarıyla ilgili Mustafa Kemal'in özel kütüphanesinde yer alan, çoğu Fransız yazarlar tarafından kaleme alınan yapıtların onun entelektüel birikimini oluşturduğu bir gerçektir. Mustafa Kemal'in "kitap seven bir fikir adamı" (İnan, 2000, s.307) oluşu, kurtuluş mücadelesinde zafere ulaşmasında en büyük etkendir. Sürekli okuyan ve etrafında da okuyan kişilerle daima fikir alışverişinde bulunan Atatürk'e göre "kültür, okumak, anlamak, görebildiğinden anlam çıkarmak, etkilenmek, düşünmek, zekâyı eğitmektir" (İnan, 1999, s.308). Osmanlı Devleti'nin küllerini silkeleyip Modern Türkiye'nin oluşumunu sağlayacak Anadolu Devriminin ateşini alevlendirmeyi başaran Atatürk için okumak, Türk sosyolog ve tarihçi Prof. Dr. Afet İnan'ın deyişiyle; 
“(...) okumak en büyük bir ihtiyaçtı. Yabancı dillerden Almancayı anlamakla beraber, iyi bildiği Fransızcada yazılmış eserleri okumayı tercih ederdi (...) Tarihî kitapları, daima harita ile takip ederek okur ve muharebeler için ayrıca krokiler çizerdi. En çok okumasını sevdiği mevzular: Tarih, coğrafya, dil, hukuk, sosyoloji, ekonomi ve sanat meseleleri idi. Roman az okurdu, fakat şiirden hoşlanır ve onları asıl şairlerden ve güzel okuyan edip arkadaşlarından dinlemesini severdi" (İnan, 2000, ss.265-266).

Bu bağlamda İnan'ın, “O'nun dikkatle okuduğu kitapları, siz okuyacak olsanız, işaretlemiş olduğu şekilleri bilmiş olursanız, kitabın bütün enteresan taraflarının belirtilmiş olduğunu görürsünüz" (İnan, 2000, s.266) deyişinden yola çıarak Mustafa Kemal'in dikkatlice okuduğu yapitlar incelendiğinde, onun Fransızcanın zengin bir kültür dili olarak sağladı̆̆ı imkânlardan faydalanmış olduğunu ve böylece Fransızcanın kendisi ile Batı uygarlığı arasında bir köprü işlevi gördüğü anlaşılmaktadır.

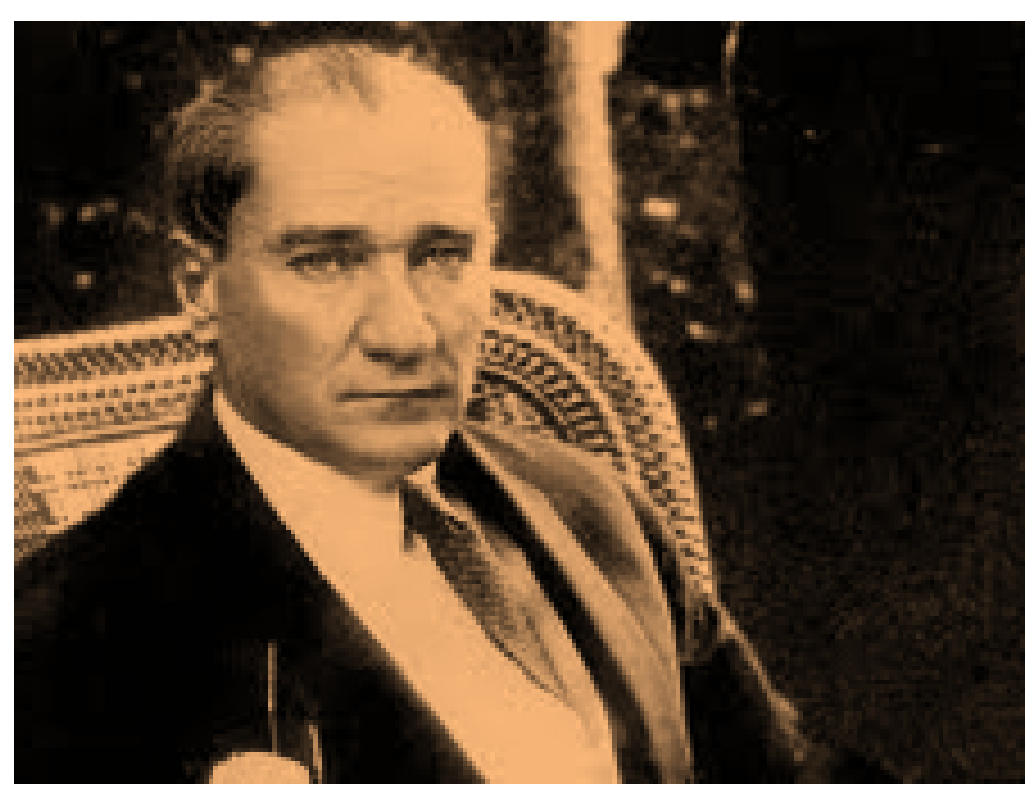

Askerî okullarda gördüğ̈̈ eğitimin yanı sıra Fransızca yazılmış ya da Almanca'dan Fransizcaya çevrilmiş askerî kitapları da okumayı ihmal etmeyen Atatürk, Fransız Albay André Constantin'in (18681931) La confiance: essai de psychologie militaire (Güven: Askerî psikoloji denemesi, 1908) yapitını dikkatlice notlar alarak okumuş ve yakınlarına da ordu psikolojisi denetiminin önemini göstermek için silah arkadaşlarına yönelik benzer bir kitap yazma isteğinden bahsetmiştir (bkz. Ünsal, 1991, ss.75-108). 1789 Fransız Devrimi'nin sihirli sözcüklerini ("Özgürlük”, "eşitlik”, “kardeşlik", "vatan”, "millet”) eserlerinde sıkça vurgulayan, Fransız kültürüyle yoğrulmuş iki büyük vatansever şair Namık Kemal ve Tevfik Fikret hayranı olan Atatürk, aynı zamanda "Batıcılık" akımı savunucularından Abdullah Cevdet'in yayımladığ Îctihad Dergisi'nin iyi bir okurudur. Bilim, teknik, düşünce ve kültürel alanda Batı uygarlığını benimsemek gerektiğini savunan yazıların yayımlandığı Îctihad Dergisi sayesinde Atatürk, başta Gustave Le Bon olmak üzere Fransız sosyologların düşüncelerini okuma imkânı yakalamıştır. “Hiçbir hükmü kendiniz kendi bilginize ve inanınıza vurmadan, filân veya falan Avrupalı muharrir diye hemen benimsemeyiniz. Onların, hele biz Türkler, bizim dilimiz ve tarihimiz üzerindeki hükümleri çok kere yanlış bellenmiş esaslara dayandığını görüyorsunuz" (Kocatürk, 1969, s.103) diyen ve "Ilim tercüme ile olmaz, tetkikle olur" (Kocatürk, 1969, s.103) düşüncesini savunan devlet ve eylem adamı Atatürk, okuduklarını kendi akıl ve mantık süzgecinden geçirmiş ve Batıyı taklit etmek yerine millî kültürle bütünleşen bir batıcılık anlayışı benimsemiştir. 
Devrimci-demokrat, materyalist filozof ve ütopik komünist olarak nitelendirilen Fransız rahip Jean Meslier'nin (1664-1729) öldükten sonra Le Bon Sens ${ }^{1}$ adiyla yayımlanan din eleştirisi yaptığı vasiyetnamesi, Atatürk tarafından dikkatlice okunmuş bazı bölümlerin altı çizilmiştir. Dinin halkı baskı altına almak ve sömürmek için kullanılan bir gerekçe olduğunu düşünen Meslier’ye göre, “bütün dönemlerde, kamuoyunun kutsallaştırdığı batıl fikirlerden hiçbir tehlike olmaksızın ayrılmak mümkün olmamıştır" (Meslier, 2005, s.345). Söz konusu cümlenin yanına iki çarpı işareti koyan Atatürk, tecrübe ve aklı rehber yaparak, din kuralları olarak nitelendirilen ancak dinle hiçbir ilgisi olmayan hurafelerin zincirinden siyaseti kurtarmaya cesaret etmiş ve dini siyasete alet edenlerle mücadele etmiş bir liderdir: “Bizi yanlış yola sevk eden soysuzlar bilirsiniz ki, çok kere din perdesine bürünmüşler, saf ve temiz halkımızı hep din kuralları sözleriyle aldata gelmişlerdir. Tarihimizi okuyunuz, dinleyiniz... Görürsünüz ki milleti mahveden, esir eden, harabeden fenalıklar hep din örtüsü altındaki küfür ve kötülükten gelmiştir" (Kocatürk, 1969, s.169). Fransız felsefe tarihçisi ve düşünürü Alfred Fouillée (1838-1912) tarafından 1903 yılında yazılan, Yunan, İtalyan, Fransız, İngiliz, İspanyol, Alman, Rus, Avusturya-Macaristan, İsviçre, Hollanda, Belçika, İskandinav milletlerinin etnik kökenleri, kültürleri ve tarihlerinin yanı sıra toplumsal ahlâk, karakter ve davranış kalıplarının anlatıldı̆̆ı Esquisse Psychologique Des Peuples Européens, Avrupa Milletleri Ruhiyatı adıyla Mustafa Rahmi Balaban tarafından 1923 yılında Osmanlı Türkçesi'ne özet olarak çevrilmiştir. Dış siyaseti sağlam temellere dayandırmak için milletlerarası ilişkilerde karşılıklı güven ve saygıyı sağlama adına barış fikrine dayalı samimi, dürüst ve açık bir politika izleyen Atatürk, Avrupa'yı tanıtan bu yapıtı altını çizerek satır satır okumuş ve kitabın sonuna "Bir gecede okudum 14/15 Eylül. Çok enteresandı. Tekrar dikkatle okunacak noktaları vardır" (Fouillé, 2012, s.31) notunu düşmüştür. Atatürk'ün dikkatle okuduğu yapitlardan biri de Fransız cerrah Dr. Victor Pauchet'in (1869-1936) her yaşta sağlıklı ve zinde kalabilmek ve toplumda saygin bir yer edinmek için tavsiyelerde bulunduğu Restez Jeunes'dür (Genç Kalınız, 1928). Özellikle de kılık kıyafet, uyku, zihnin daha aktif hale gelmesini sağlayan doğru nefes teknikleri ve beden dili ile ilgili özdeyişlerin altını çizerek okuyan Atatürk'e göre; “(...) medeniyim diyen Türkiye'nin hakikaten medenî olan halkı, baştan aşağıya dış görünüşüyle dahi medenî ve olgun insanlar olduğunu fiilen göstermeye mecburdur (...) Çok kiymetli bir cevheri çamurla sıvayarak dünyaya göstermekte mâna var mıdır? Bu çamurun içinde cevher gizlidir, anlamıyorsunuz, demek doğru mudur? Cevheri gösterebilmek için çamuru atmak elzemdir, tabiidir" (Kocatürk, 1969, s.80).

$\mathrm{Bu}$ nedenle gerek kılık kıyafeti gerekse de güçlü ve kendinden emin beden dili ile lider kişiliğini tamamlayan Atatürk, Türk milletine her zaman canlı örnek olmuş ve çağdaş toplumlarda itibar görebilmek için dış görünüşün ne kadar etkili olduğunu her fırsatta dile getirmiştir.

Atatürk'ün özel işaretler koyarak ve notlar düşerek okuduğu yapıtlardan biri de Fransız doğubilimci, sinolog ve Türkolog Joseph de Guignes (1721-1800) tarafından kaleme alınan Türk Âleminin tarihini ele alan ilk eser sayılan Histoire Générale Des Huns, Des Turcs, Des Mogols, et Des

\footnotetext{
${ }^{1}$ Dr. Abdullah Cevdet'in Aklı Selim adıyla Fransızcadan çevirdiği bu yapıt, 1928'de Arap, 1929'da ise Latin harfleriyle olmak üzere iki kez yayımlanır. Dr. Abdullah Cevdet, eski harflerle olan ilk basımın bir örneğini, Gazi Mustafa Kemal'e 29 Aralık 1928'de eliyle yazdığı şu ithafla sunmuştur: "En büyük acizden en büyük iktidara." Günümüzde ise Sağduyu Tanrısızlı̆̆ın İlmihali olarak yayınlanmaktadır.
} 
Autres Tartares Occidentaux (Hunların, Türklerin, Moğollarm ve Sair Tatarların Tarih-i Umumisi, 1757) adlı yapıttır. En eski Çin tarihi kayıtlarından faydalanılarak Türk Tarihinin kapsamlı bir biçimde incelenmeye çalışıldığı yapıtta, yaşam tarzları ve karakteristik özellikleri farklılıklar göstermesine rağmen kavimlerin nasıl yüksek kültüre sahip oldukları ve devlet olabilme yolunda verdikleri mücadeleleri gözler önüne serilir. Sahip olduğu derin tarih bilgisi sayesinde, geleceğe doğru adımlarla ilerlemenin tek yolunun tarihi iyi bilmek, tarihte büyük izler bırakmış kişilerden feyz almak ya da yaşanılanlardan ders çıarmak olduğunun farkında olan Atatürk, millî şuuru uyandıracak millî tarih yazımına her zaman önem vermiştir. Bunun en büyük kanıtı da Ulu Önder'in kaleminden çıkan Ulusal Kurtuluş Mücadelesi'nin gerçek hikâyesi, Cumhuriyet'in anitsal yapitı Nutuk'tur.

“Siyasî, askerî zaferler ne kadar büyük olursa olsunlar, ekonomik zaferlerle taçlandırılamazlarsa husule gelen zaferler devamlı olamaz, az zamanda söner" (Kocatürk, 1969, s. 205) diyen Atatürk, milletin refahı için ekonomik kalkınmanın gerekliliğini vurgulamış; bir milletin yükseliş ve çöküş sebeplerinin yalnızca siyasi, askerî ve toplumsal sebeplere bağlı olmadığı, o milletin ilerlemesinde ya da gerilemesinde ekonominin de çok büyük bir rol oynadığını dile getirmiştir. Fransız ekonomist ve iktisadi düşünce tarihçisi Charles Gide (18471932) tarafından yazılan Cours d'Économie Politique (İlm-i İktisad Dersleri, 1917) yapıtını satır satır okuyan Atatürk, ekonomi biliminin insan toplumları için ne kadar önemli olduğunun bilincindedir.

Fransızca felsefe, tarih, sosyoloji ve askerî yapıtların yanı sıra Fransız romanı da okumayı ihmal etmeyen Atatürk, edebiyatın Fransızların karakterinin oluşmasında ve uygarlık anlayışlarında büyük bir rol oynadığının bilincindedir. 19 Kasım 1916 tarihinde Bitlis'te bulunduğu sırada Atatürk hatıra defterine, Fransiz yazar Alphonse Daudet'nin (1840-1897) Sapho, Mœurs Parisiennes (Sapho, Paris Adetleri, 1884) adlı yapıtını okumayı bitirdiğini yazar ve romanı özetler (Tezer, 2008, ss.72-73).

\section{YÖNTEM}

Ortaylı, 14 Kasım 2015 tarihinde Almanya'da düzenlenen bir konferansta yaptığ konuşmada, “(...) İlla tarihî bir dostluk arıyorsak o Fransa’dır. Onu bilmemiz lazım. Çünkü Fransa ile Türk İmparatorluğunun menfaatleri her zaman bağdaşmıştır. Kime karşı İspanya ve Almanya'ya karşı. XVI. XVIII. asırda bu böyledir, hatta XIX.'da da böyledir" diyerek, temelleri yüzyıllar öncesine dayanan Türkler ile Fransızlar arasındaki dostluk köprüsünü anımsatır. Ortaylı sayesinde unutuşa karşı mücadele eden hafıza bir kez daha görevini yerine getirmiştir.

$\mathrm{Bu}$ çalışmada, gerek Atatürk'ün fikir dünyasını etkileyen Fransız düşünür ve yazarların gerekse de Yeni Türkiye'nin oluşumuna ve gelişimine bizzat tanıklık etmiş Fransızların, Yeni Türkiye ile inşa edilen kolektif hafızanın oluşumunda nasıl etkin rol oynadıklarını yorumlamak, yedekte bekleyen unutuşa engel olmaya yardımcı olmak amaçlanmıştır. Bu amaç doğrultusunda yapılacak eleştirel okumalar, tasarlanan geleceği hatırlanan geçmişe bağlayan hafızayı detaylı olarak inceleyen Maurice Halbwachs, Paul Ricoeur ve Paul Connerton tarafından kaleme alınan yapıtlar çalışmanın kuramsal alt yapısını oluşturacaktır. 
Hafıza, geçmişte edinilmiş deneyimleri ya da bilgileri, bireysel ya da kolektif olarak anımsama becerisidir. Başlangıçta hafıza üzerine düşünceler bireysel bir kavrayış olarak ele alınırken daha sonraları kolektif hafıza anlayışından söz edilmeye başlanmıştır. "Hafızanın konusu geçmiştir" (bkz. Ricoeur, 2012, ss.34-40) diyen Aristoteles'e göre hafıza, geçmiş zamanda yaşanılanların hatırlanması ile ilgilidir. Zamanı uzamdan ayırarak zaman kavramına farklı bir bakış açısıyla yaklaşan XX. yüzyıl düşünürlerinden Bergson'a göre şimdi, geçmiş ve geleceğin birleşimidir. Geçmişin şimdide yaşadığı yer hafızadır. Hafıza, geçmişi geçmişte bırakmayarak şimdiye taşır, bir başka deyişle geçmişi şimdi içinde kavramamızı sağlar.

Hafızanın bütünüyle bireysel olduğunu vurgulayan yani birinin anılarının bir başkasının hafızasına aktarılamadığı, hafızanın şimdiki zamanda anımsanan geçmişe ait olması ve bu geçmişin de anımsayanın geçmişi olduğu düşüncesi üzerine kurulan içebakış geleneğinin öncüsü olan Augustinus, Platon ve Aristoteles'in düşüncelerinin de yansıması olarak hafızanın bireyselliğini savunur. Orta Çağ’da Augustinus'un ele aldığı hafıza kavramı, kişinin geçmişindeki izlenimlerinin anımsanmasına odaklanmıştır. Augustinus, pişmanlıklarını, ümitlerini, gerçeğe ulaşmak için çektiği 1stıraplarını anlatarak bir nevi günah çıkarttığı İtiraflar adlı yapıtıyla hafızanın karmaşıklığını ve mükemmelliğini betimler. Dünya yazınında ilk büyük anı anlatısı olarak kabul edilen bu yapıtta

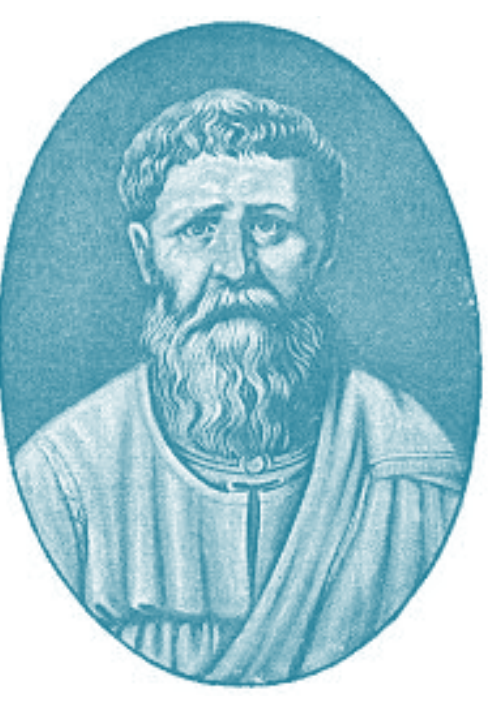

Augustinus hafızanın duyunun getirdiği türlü imgelerle dolu bir hazine olduğunun altını çizer. Augustinus'un deyişiyle hafıza, "kiler, depo, çeşit çeşit anılar buralarda depolanır, saklanır; bütün bunları hafıza toplar, gerektiğinde anar ve ardından yine o koskoca mağarasına, kimsenin sırrına eremediği o kuytulara" (Ricoeur, 2012, s.117) saklar. Geçmişi şimdi içerisine taşıyarak zamanı içselleştiren Augustinus, aynı zamanda hafızayı da içselleştirerek bireyselliğe vurgu yapar:

“Hafızamda andığım her şeyin istediğim gibi hatırlanması da kanıtlıyor ki bu eylemleri içeride hafızamın sarayındaki uçsuz bucaksız avluda gerçekleştiriyorum (...) Bu noktada kendimle karşılaşırım, kendimi anımsarım, yaptığımı, nerede ve ne zaman yaptığımı ve onu yaparken neler hissettiğimi anımsarım. Evet, hafızanın gücü öylesine büyüktür ki anımsadığımı bile anımsarım" (Ricoeur, 2012, ss.117-118).

İçebakış felsefesi akımı içinde değerlendirilen bir başka düşünür John Locke'a göre ise, bilinç ve hafıza bir ve aynı şeydir, herhangi bir tözsel dayanak aramak gerekmez. Benzer şekilde, Edmund Husserl de kısa süreli hafıza ile uzun süreli hafıza ayrımını yaparak, kurucusu olduğu Fenomenoloji akımıyla, her şeyin özünü bilinç nesnesi olarak belirler. İlk olarak Fransız filozof ve sosyolog Maurice Halbwachs, La Mémoire Collective (Kolektif Hafıza, 1950)'de hafızayı doğrudan grup ya da toplum adını verdiği kolektif bir varlığa bağlar:

İkinci Dünya Savaşı sırasında esir düştüğü toplama kamplarında yaşanılanlara tanıklık eden Fransız filozof ve tarihçi Paul Ricoeur (1913-2005), insanın bireysel ve kolektif tarihinde özellikle de XX. yüzyılda yaşanılanların hatırlanması ve unutulması hakkında düşüncelerini felsefi bir 
düzlemde aktardığı Hafiza, Tarih, Unutuş (La mémoire, l“chistoire, l'oubli, 2000) adlı yapıtında, hafıza ile tarih, bireysel hafıza ile kolektif hafıza, anımsayış ile unutuş arasındaki ilişkileri geniş bir yelpazede sunar. Tarihin yazılışını, Platon'un Phaidros'da dile getirdiği “(...) daha çok bilgi, daha çok bilim ve daha çok hafıza sağlayacak bilgi; bilginin ve hafızanın ilacı" (Ricoeur, 2011, s.161) pharmakon'a yani ilaç mı zehir mi yoksa ikisi birden mi olduğu bilinmeyen bir ilaca benzeten Ricoeur, hafıza ile yazılı tarih arasındaki ilişki düzleminden bahseder: "Tarih yazımın hafızayı genişletme, düzeltme ve eleştirme, böylece hem bilişsel hem de pragmatik alanda kendi hatalarını düzeltme kapasitesine olan güvenin sağlamlığına işaret eder" (Ricoeur, 2011,s.168). Zaman, mekân ve tarihsel anlatılar üzerine inşa edilen tarih yazımı, hafızayı aydınlatıp eğitmesinin yanında düşüşe geçmiş bir hafızayı canlandırabileceğini düşünür. “Uzak geçmişle ilgili anlatıları karanlığa gömen sır havası, kendi anılarımızda boşluklar doldukça, karanlıkları dağıldıkça azalır. Ufukta bireysel hafızayı, kolektif hafızayı ve tarihsel hafızayı bir araya getirecek bütünsel bir hafızanın var olması dileği vardır. Bu dilek Halbwachs'ın ağzında, Bergson'a (ve Freud'a) yakışacak bir haykırışa dönüşür: “Hiçbir şeyi unutmayınız” (Ricoeur, 2011, s.440). Nietzsche'nin Tarihin Yaşam İçin Yararı ve Sakıncası-Zamana Aykırı Bakışlar 2'de sorgulamaya başladığı Paul Ricoeur'nün ideoloji eleştirisi bağlamında tarihyazımın kök salacağı alanı oluşturan kolektif hafızayı ele alırken elverişli gördüğü hafızanın kullanılış ve suiistimal ediliş biçimleri, engellenen, manipüle edilen (kötü niyetle yönlendirilen) ve zorunlu hafıza olarak temsil edilir. Hafızanın unutkan olduğu bu nedenle, anımsamak yerine unutuşu şeçen hafızada "unutuşlar, perde-anılar, başarısız edimler kolektif hafıza ölçeğinde devasa boyutlara ulaşabilir; bunları bir tek tarih, özellikle de hafıza tarihi gün ışığına çıkarabilir" (Ricoeur, 2011, s.491). Hafızanın anlatısal işlev yoluyla kimliğin oluşturulmasına katıldığını söyleyen Ricoeur, gönül okşayan ya da korkutan söylemlerle beslenen kuruluş, şan şeref ve aşağılama anlatıları, hafızanın ideoloji hâline getirilmesine olanak sağladığını düşünür. Bu şekilde dayatılan hafızanın görünürde izinli bir tarih, resmi tarih, kamuca öğrenilmiş ve kutlanan tarih; gerçekte ise öğretilmiş bir hafıza, zoraki ezberdir (bkz. Ricoeur, 2011, ss.104-105). Şimdiki zaman ile geçmiş arasındaki ilişkinin bekçisi olan hafıza, tarihin ana rahmidir, hafızanın görevi anımsamak aynı zamanda unutmamaktır. “(..) hafıza ile tarihin ayak izleri üstünde unutuşun imparatorluğu kurulmaya başlıyor; istemeye istemeye kendi içinde ikiye bölünmüş bir imparatorluktur bu, bir yanında izlerin tamamıla silinme tehdidi, diğer yanında anamnèsis kaynaklarının yedeklenmiş olmasının verdiği güvence vardır"' (Ricoeur, 2011, s.16).

Hafızayı doğrudan grup ya da toplum adını verdiği kolektif bir varlığa bağlayan Fransız filozof ve sosyolog Maurice Halbwachs, Les cadres sociaux de la mémoire (Hafızanın Toplumsal Çerçeveleri, 1925) ve La Mémoire collective (Kolektif Hafıza, 1950) adlı iki önemli yapıtıyla, kişilerin, anılarını bir toplumsal gruba üyelikleri yoluyla edinebildiklerini, belleklerinde bir yere yerleştirebildiklerini ve anımsayabildiklerini savunur. Anılarımızı bizi kuşatan maddeler ortamına bağlayarak koruduğumuzu ve bu nedenle anımsamak için başkalarına gereksinim duyduğumuzu ileri sürer: "ancak bir ya da birçok grubun bakış açısına yerleşmek ve bir ya da birçok düşünce akımı içinde gezinmek koşuluyla anımsayabiliriz (bkz. Halbwachs, 1950). Bu nedenle, bireyin tek başına anımsaması imkânsızdır; ancak bir ya da birçok grubun bakış açısına yerleşerek anımsaması mümkün olabilir. Bağlı olduğumuz grubun ortak hafızasını taşırız. Böylelikle 
Halbwachs'ın önerdiği grup içinde tanıklarla gerçekleşen anımsama yöntemi, grup dağıldığında ya da tanıklar öldüğünde sonuçsuz kalır.

Toplumlar nasıl anımsar? (How societes remember, 1989) yapitında "İnsan gruplarının hafızası nasıl taşındığ 1 ve nasıl korunduğu" sorusuna yanıt arayan Paul Connerton, bugüne ilişkin deneyimimizin, büyük ölçüde geçmiş hakkında bilgimize dayandığını, günümüz dünyasını, geçmişin olaylarıyla ve nesneleriyle nedensellik bağlantıları içindeki bir bağlamda, yani geçmişin, o anda yaşamadığımız olayları ve o anda algılamadığımız nesneleri bağlamında yaşadığımızı söyler. Connerton, tüm totaliter rejimlerin uyruklarının kafalarını tutsaklaştırmaya, onları belleklerinden ederek başladığını bunu da sistemli unutturma yöntemi kullanarak yaptıklarını savunur. Geçmişi kendimize, onu temsil eden sözcüklerle ve imgelerle yani geçmişin yeniden canlandırıldığı anma törenleri ya da açık söz ve başvurarak canlandırmaksızın bilinçli olarak da beceri gerektiren belli bazı eylemleri (bedensel pratikler) sürdürme yeteneği ile koruduğumuza dikkat çeker (bkz. Connerton, 1999, s.113).

Millî Mücadele ve Cumhuriyet Dönemine ilişkin Fransız yazar, siyasetçi ve askerlerin kaleminden çıkan anlatılar, yalnızca o dönemin ayrıntılarını kaydetmeyi değil, aynı zamanda Türk-Fransız dostluğunun göstergesi olarak okuru bu dönemin tanığ1 kılmayı da amaçlar. Türklere ve Türkiye'ye sempati duyan Fransızların hem Fransız hem de Türk toplumunda ortak hafızanın ve kamuoyunun oluşumunda etkili olduğu inkâr edilemez. "Tarih hafızanın geçmiş üzerindeki tanıklığını genişletebilir, tamamlayabilir, düzeltebilir, hatta yadsıyabilir, ama bu tanıklığı yok edemez" (Ricoeur, 2011, s.547). Nasıl ki yeniden doğuşumuza tanıklık eden bu yapıtlar, ulusal tarihsel hafızamız için önemli bir parça ise, aynı zamanda Fransa tarihinde bütünsel bir tablo yaratmak için yapbozun bir parçasını temsil eder.

Mustafa Kemal Atatürk'ün okuduğu Fransızca kaynaklar, Fransızlarla yazışmaları, Fransız gazetecilerle yaptığı söyleşiler, Millî Mücadele ve Cumhuriyet Dönemi Fransız tanıklıklarının kaleme aldığı yapıtlar ve makaleler, konu ile ilgili Fransız basınında çıkan haberler, bu çalışmanın araştırma evrenini ve örneklemini oluşturmuştur.

\section{ATATÜRK'ÜN DIŞ DÜNYAYA AÇILAN PENCERESİ: FRANSIZ DİLI}

"Dünyada her şey için, maddiyat için maneviyat için, hayat için, muvaffakiyet için en hakikî yol gösterici ilimdir, fendir" (Kocatürk, 1969, s.103) diyen Atatürk'e göre okuma, öğrenmek için, ilham almak için ve her şeyden önemlisi karşılaşılan her türlü sorunla başa çıkabilecek bilgiyi edinmek için yapılmalıdır. Okul sıralarından itibaren bitmek bilmeyen bilgi açlığıyla yazınsal yapıtlardan siyasipolitik ve felsefi yapıtlara kadar çoğu Fransız yazarlar tarafından kaleme alınan yapıtları sabahlara kadar okuyan, önemli gördükleri

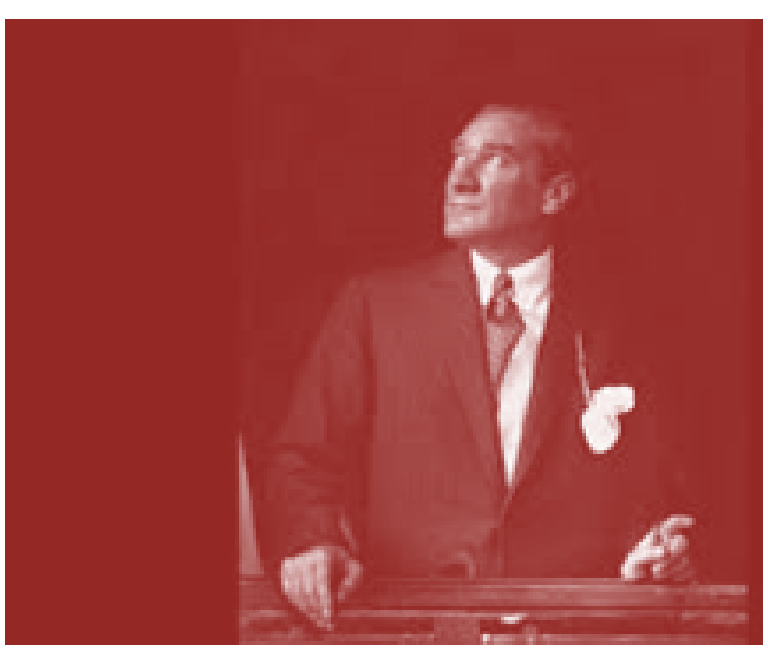


satırların altını çizen, notlar alan kelimenin tam anlamıyla "aktif" bir okur diyeceğimiz Atatürk için Fransız Dili, dış dünyaya açılan bir pencere olmuştur.

Atatürk'ün Fransızca yapıtlarını okumasındaki sebeplerden biri de harp okuluna girişinde kendisine yararlı olacak askerî-meslek ya da ilgilendiği konularda Türkçe dilinde yazılmış yapıtların olmayışından kaynaklanır. XVIII. yüzyıla kadar medreselerde ve diğer eğitim kurumlarında Müslümanların Batı dillerini öğrenmeleri yasaktı. XVIII. yüzyılın sonuna doğru III. Selim'in tahta çıkışı ve yeni eğitim kurumlarının açılışıyla, eski katılığını yitirmeye başlar ve askerî okullarda ilk kez Fransızca eğitimi başlar, askerî-meslek kitaplar Osmanlı Türkçesine çevrilir ve İstanbul Fransa Konsolosluğu tarafından basılır. 1826 yılında Yeniçeri Ocağını kaldıran ve Batılılaşma yolunda önemli gelişmelere imza atan II. Mahmut, batılı tarzda eğitim vermek amacıyla İstanbul'da ilk modern tıp okulu olan Mekteb-i Tıbbiye-i Şahane'yi açmış ve burada Fransızca gerek Fransız eğitimciler gerekse de bu dile çok iyi derecede hâkim yerli eğitmenler tarafından öğretilmiştir. Artık Fransızca bilimsel ve resmî dil olarak benimsenmeye başlamıştır. Fransızcaya duyulan hayranlık öylesine büyüktü ki önceleri mektep, tıbbiye ve kışla olarak kullanılan ve 1868 yılında Mekteb-i Sultanî adıyla faaliyete geçen Galatasaray Lisesi'nde eğitim dili Fransızca olarak benimsenmiştir. Atatürk de gençlik yıllarında Fransızca öğrenmeye büyük bir önem ve öncelik vermiş askerî okulda aldığ getirdiği gibi Fransızcasını geliştirmek için Selanik'te Frerler Okulu'nun özel kurlarına devam etmiştir. Harp okulundan mezun olduktan sonra da Fransızcasını ilerletmeyi sürdürmüş, Balkan Savaşları sırasında şehit düşen arkadaşı Ömer Lütfi Bey'in Fransız kültürüne ve diline oldukça aşina olan İtalyan eşi Madam Corrine ile Fransızca mektuplaşmaları da Fransızcasının gelişmesine büyük katkı sağlamıştır. Atatürk'ün tarihe sşık tutan önemli bilgiler içeren bu mektupları yazacak kadar Fransızcasının ilerlemiş olduğuna şaşıran Madam Corrine, bu mektupları başkasına yazdırıp yazdırmadığını bir mektubunda ona sormuştur. Atatürk'ün verdiği yanıt ise şu şekilde olmuştur:

“Bana yazıyorsun ki son mektubumda evvelkiler kadar imla yanlışı olmadığı için, bundan mektuplarımın bir başkasının kalemiyle yazıldığı neticesi çıkarmışsın. Bu küçük dikkati senin tarafından bir cemile (compliment) telakki ederim, zira ben, bildiğim kadar Fransızcanın üzerinde hiçbir hayale kapılmıyorum, bu dili Türkçe kadar iyi bilseydim size yalnız daha sık mektup yazmakla kalmaz, size karşı samimi bağlılığımı daha zarif ve daha seçkin bir şekil altında ifade etmeye muvaffak olurdum" (Özverim, 2007, s.39)

12 Ocak 1914 tarihli mektubunda ise Atatürk, gençliğinden itibaren "cumhuriyet" fikrini benimsediğini ve son nefesine kadar bu uğurda mücadele içinde olacağını bildirir:

"Benim ihtiraslarım var, hem de pek büyükleri; fakat bu ihtiraslar, yüksek mevkiler işgal etmek veya büyük paralar elde etmek gibi maddî emellerin tatminine taalluk etmiyor. Ben bu ihtiraslarımın gerçekleşmesini vatanıma büyük faydaları dokunacak, bana da liyakâtla ifa edilmiş bir vazifenin canlı iç rahatlığını verecek büyük bir fikrin başarısında arıyorum. Bütün hayatımın prensibi bu olmuştur. Ona (bu büyük fikre) çok genç yaşımda sahip oldum ve son nefesime kadar da onu muhafaza etmekten geri kalmayacağım" (Özverim, 2007, ss.40-41). 
13 Mayıs 1914 tarihli mektubunun son bölümünde Atatürk, 14 yıl sonra gerçekleştireceği harf devriminin bir denemesi olarak ilk kez Latin harflerini kullanarak düşüncelerini Türkçe ifade etmiştir.

6 Mart 1916 tarihinde Siirt'ten yazdığı mektubunda, Fransız tarihçi, yazar ve gazeteci François-Auguste Mignet (1796-1884), Histoire de la Révolution française de 1789 jusqu'en 1814 (1789'dan 1814'e kadar Fransiz Devrimi Tarihi, 1824) yapıtından bir alıntıya yer vermesi, Fransız Devrimi düşüncelerinin kendisini ne denli etkilemiş olduğunun göstergesidir. 14 Temmuz 1922'de General Mougin tarafından Fransız Devrimi'nin yıl dönümünü kutlamak için verilen davete şeref konuğu olarak katılan Atatürk, konuşmasında adı geçen yapıttan alıntı yapar: "Bu sayfanın geri kalan kısmını önümde bulunan bir kitaptan aldığım bazı sözlerle dolduruyorum: "Orduların hâlâ devam eden mekanik hareketleri sona ermek üzereydi. Zira halkın hareketi söndügüü zaman askerler bulunmaz. Ruhların takati bittiği zaman generaller kendilerine gelemezler ve zaferler askerlerle, generallerle ve para ile birlikte sona erer..." (Özverim, 2007, ss. 57-58).

Atatürk bu konuşmasında, Fransızların 14 Temmuz millî bayramının ruhunda hürriyet ve istiklâl aşkını taşıyan bütün milletlerin bayramı olduğunu ve henüz bağımsızlıklarını ilan etmemiş milletlere de örnek olacağını dile getirir. O halde Fransızların da hürriyet ve istiklâl uğruna mücadele veren Türk Milletine destek olmaları gerekmektedir: “Efendiler, bizim Asya'yı kıyam ve cidale sevk edişimiz, Fransız milletini kahramanca hareketlere sevk eden sebeplerden daha az kuvvetli ve daha az mantıkî değildir, çok ümit ederim ki hürriyet ve istiklâli için milyonlarca evlâdını topraklara gömmüş olan Fransa'nın bugünkü çocukları da Türkiye'mizin haklı isteklerini kavramış bulunsun (...)"' (Tansu, 2011, ss.607-612).

Tüm dünyaya özgürlük düşüncesini aşılayan Fransız devrimi, Mustafa Kemal'in gerçekleştireceği devrim hareketlerine kaynaklık etmiş ancak kendisinin de dile getirdiği gibi Türk devrimi yönünü kendisi belirlemiştir: “Fransa devrimi bütün dünyaya özgürlük düşüncesini estirmiştir ve bu düşünce şimdi de temel ve kaynak olmaktadır. Ama o tarihten beri insanlık ilerlemiştir. Türk demokrasisi Fransa devriminin açtığı yolu izlemiş ama kendine özgü seçkin özelliğiyle gelişmiştir. Çünkü her ulus, devrimini toplumsal olan hal ve durumuna ve bu düzen değiştirilmesi ve devrimin oluş zamanına göre yapar" (İnan, 1999, s.330).

13 Mayıs 1914 tarihli mektubunu XIX. yüzyıl Fransız romantizm akımının önemli savunucularından yazar ve aynı zamanda siyasetçi François-René de Chateaubriand'ın (1768-1848) düzyazı şiir olarak ta kabul edilen Les Natchez (1827) adlı yapıtından bir alıntıyla mektubunu sonlandırır: "Son söz: "Ya hiç doğmamış olmak veya hiç unutulmamak isterdim" (fr. Je voudrais n'être pas né, ou être à jamais oublié.( Chateaubriand, 1827, s.185.)

Atatürk'ün Fransa bilgisi sadece kitaplar aracılığıyla olmamış, 1910 yılında Picardie Manevraları'nda Osmanlı Ordusu'nu temsilen gözlemci olarak bulunmuş ve bu gezi sayesinde fesin Batılılar tarafından gülünç bulunduğu kanaatine vararak 1925 yılında gerçekleştirilecek olan şapka ve kıyafet devrimine zemin hazırladığı söylenebilir. Bunun yanı sıra Picardie Manevraları sayesinde başta Mareşal Ferdinand Foch olmak üzere çok fazla Fransız askerlerle tanışma imkânı bulmuştur. 
Atatürk'ün görüştüğü Fransız siyaset adamı ve diplomatlardan Henry Franklin-Bouillon ise Sakarya Savaşı'ndan sonra 20 Ekim 1921'de Fransız hükümeti adına Ankara Anlaşması'nı imzalamak üzere Ankara'ya gelmiş ve ikili arasında Mondros Mütarekesi'nden Lozan Barış Konferansi'na uzanacak bir dostluk bağ kurulmuştur.

Mustafa Kemal, Sofya'da Askerî Ataşe olarak görev yaptığı dönemde, can dostu Salih Bozok'a 18 Ekim 1914 tarihinde gönderdiği mektubunda, Hispano-belçika uyruklu şair Léon van Montenaeken'ın Fransızca kaleme aldığı tek şiir kitabında (Rimes futiles (1879) yer alan “Peu de choses!" 2 başlıklı şiirini bizzat tercüme eder:

Hayat kısadır

Biraz hayal

Biraz aşk

Ve sonra allahaısmarladık.

Hayat boştur

Biraz kin

Biraz ümit

Ve sonra allahaısmarladık

Ortak arkadaşları Fuat Bulca'nın evlenmesi üzerine duyduğu mutluluğu dile getirdiği mektubunda bu dizelere yer vererek ölümüne kadar yanından hiç ayrılmayacak olan can yoldaşına "Salih, bunları ezberle. Ve sen hayatı nasıl anladınsa ona göre bunlardan birini benimse" (Atatürk, 2010) tavsiyesinde bulunarak mektubunu bitirir.

Ünlü Şair Ali Ulvi Elöve (1881-1975), her zaman büyük bir öğrenme açlığı içerisinde olan Mustafa Kemal'in J.J. Rousseau'ya olan ilgisinden bahseder (Akay, 2005). 1 Aralık 1921'de, Büyük Millet Meclisi vekillerinin önünde yaptığı konuşmasında, siyasi fikirleriyle Fransız Devrimi'ni etkileyen ünlü düşünür Jean Jacques Rousseau'nun Du Contrat Social (Toplum Sözleşmesi, 1762) kitabına işaret eden Atatürk'ün, Türk Devrim hareketlerine yön veren özgürlük ve egemenlik kavramların oluşumunda Rousseau'nun fikirlerinden etkilendiği açıktır:

"Bu Meşrutiyet kuramlarını bulan en büyük filozofların, bu kuramları kurmak için çalıştıkları esasları inceledim, bunların içeriğini anlamaya çalıştım. Benim gördüğüm şudur: Düşünmüşler ve nasıl yapalım da bu zorba kuvvet, o toplumsal ve ulusal iradenin aşağısında kalabilsin ya da sıfıra ulaşabilsin diyorlar. Ve bunu başaramamak yüzünden büyük ve derin bir istırap duyuyorlar. Jean Jacques Rousseau'yu baştan sona kadar okuyunuz! Ben bunu okuduğum vakit, gerçek olduğuna inandığım bu kitap sahibinde iki esas gördüm. Birisi bu 1stırap, diğeri bir cinnettir. Merak ettim, özel durumunu inceledim. Anladım ki, bu adam mecnun idi ve cinnet durumunda bu eserini yazmıştır. Dolayısıyla çok ve pek çok dayandığımız bu kuram, böyle bir dimağın ürünüdür" (Atatürk'ün Söylev ve Demeçleri, s.216).

Bununla birlikte "Hürriyet ve bağımsızlık benim karakterimdir" (Kocatürk, 1969, 290) diyen Atatürk, kütüphanesinde bulunan Montesquieu'nün De l'Esprit des lois (Kanunların Ruhu Üzerine)

\footnotetext{
${ }^{2}$ Bu dizelerin bazı Türk kaynaklarda Fransız şair Paul Verlaine'in Sérénade adlı şiirine ait olduğu söylenmektedir ki bu yanlıştır. Ayrıca Mustafa Kemal'in mektupta yer alan “Bir Fransız şairi hayatı şöyle tavsif ediyor(...)” ifadesinden yola çıarak Léon van Montenaeken Fransız şair olarak algılanmış gerçekte ise Hispano-belçika uyruklu olup Frankofon edebiyatında adı çok duyulmamıştır (Palenque, 2018)
} 
adlı ünlü yapıtını da dikkatlice incelediği, özellikle de "cumhuriyet rejimi" ile ilgili kanunların altını çizerek okuduğu görülür: “Cumhuriyette, yönetim yetkisi tüm milletin elinde olursa buna Demokrasi denir (...) Egemenliği elinde bulunduran millet layıkıyla yapabileceği her şeyi bizzat kendisi yapmalı; layıkıyla yapamayacağı şeyi de temsilcilerine yaptırmalı" (bkz. Ünsal, 1991, ss.2743).

Türk Tarih Kurumu kuruluş aşamasında tarih kavramı ve anlayışı üzerine en yeni düşüncelerin incelenmesi için Atatürk, Fransız filozof Henri Fernand Berr (1863-1954) tarafından yönetilen evrensel tarih derlemesi L'Évolution de l'humanité ciltlerini tarih ile uğraşan arkadaşlarına görev paylaşımı yaparak inceletmiştir (Akay, 2005, s.66).

\section{FRANSIZ DEVLET ADAMLARININ HAYRAN KALDIĞI TÜRK: GAZİ MUSTAFA KEMAL ATATÜRK}

Sakarya zaferinden otuz yedi gün sonra 20 Ekim 1921 tarihinde Ankara'da imzalanan Ankara Anlaşması'nın mimarı Fransız eski bakanlardan Henry Franklin-Bouillon (1870-1937), Mustafa Kemal ile birçok kez görüşmüş ve bu görüşmelerde Atatürk, -Nutuk'ta da detaylı olarak anlatıldığı üzere- Eski Osmanlı İmparatorluğu'ndan yeni bir Türkiye Devleti doğduğunu, Türk Ulusunun istisnasız tüm bireylerinin yalnız bir amaç etrafında toplandığını ve bunun uğruna sonuna kadar kanını akıtmaya devam edeceğini belirtmiştir. Görüşmeler neticesinde Türk Ulusunun bağımsızlık mücadelesinde ne kadar kararlı olduğunun bilincine varan Fransa Hükümeti, Türkiye'nin tam bağımsızlığını onayladığı Ankara Anlaşması'nı imzalar. “Bu anlaşma ile ulusal davamız, ilk defa olarak Batı devletlerinden biri tarafından onaylanmış ve açılanmış oldu. Mösyö Franklin Bouillon, bundan sonra da birkaç kere Türkiye'ye gelmiş, Ankara'da ilk günlerde aramızda kurulan dostluk duygularını gösterme yollarını aramıştır" (Atatürk, 2017, s.422) Bilâl Niyazi Şimşir'in "Atatürk et Ses Amis Français" (Atatürk ve Fransız Dostları) başlıklı makalesinde yer alan Franklin-Bouillon ile Mustafa Kemal arasındaki yazışmalardan da anlaşılacağı üzere, aynı barış arzusunu paylaşan ikilinin, anlaşma sonrasında da görüşmelere devam etmesi iki ülke arasındaki mutlak siyasi güvenin oluşumuna katkı sağlamıştır. Nitekim 27 Ağustos 1924 tarihli telgrafında Franklin-Bouillon, Lozan Konferansının ilk aşamalarında Fransa'nın, siyasi çıkarlar nedeniyle İngiltere'nin yanında yer alarak Türkler ile görüş ayrılıklarına düşmesine rağmen sonunda barış anlaşmasını onaylamayı kabul etmiş olmasından dolayı duyduğu mutluluğu dile getirerek zedelenen Türk-Fransız ilişkilerinin onarılmasını temenni eder. Mustafa Kemal'e General Mougin aracilığıyla gönderdiği 18 Mayıs 1930 tarihli mektubunda Franklin-Bouillon, hastalığından, Joung planına karşı verdiği siyasi mücadeleden ve aralarındaki dostluğun, iş birliğinin gerekliliğinden bahseder. Mustafa Kemal'in verdiği yanıtta ise, FranklinBouillon'u Ankara'da tekrar ağırlamak istediğini, Türkiye ve dış ilişkiler için büyük önem taşıyan ve zihnini meşgul eden sorunun borçlar olduğunu ve iş birliği içinde olmayı ümit ettiğini dile getirir (bkz. Şimşir, 1981, ss.257-272).

Fransa ve İslam arasındaki "sadık birliğin" savunucularından Fas'taki Fransız sömürge valisi Mareşal Lyautey, 1920 yılının sonundan itibaren Yeni Türkiye'nin tarafında olmuş ve TürkiyeFransa dostluğu için çabalamıştır. Mustafa Kemal, Berthe Georges-Gaulis'e, Mareşal Lyautey'e 
iletmesi için verdiği 23 Aralık 1921 tarihli mektubunda Türkiye'nin bağımsızlık mücadelesinde, başta Mareşal Lyautey olmak üzere en üst düzey liderler aracılığıyla Fransa'nın verdiği destekten ve iki ülke arasında Ankara Anlaşması ile kurulan dostluğun meyvelerini vermeye başladığından dolayı duyulan memnuniyetini dile getirmiştir. Mareşal Lyautey ise 20 Mart 1922 tarihli mektubunda, Mustafa Kemal'in mektubundan çok etkilendiğini ve haklı davasının savunucusu olduğunu belirtir (Şimşir, 1981, s. 264).

Fransız yazar ve devlet adamı Édouard Marie Herriot (1872-1957), Türkiye'de laik cumhuriyet rejiminin kurulabileceğine inanmış ve "radikal-sosyalist Fransızların ilk kuzenleri olarak" gördüğü Kemalistlere karşı sempatisini göstermekten çekinmemiştir. Herriot, Orient (Doğu, 1934) yapıtını yayınlamadan önce, 1933 yılında Yalova'da Atatürk'ü ziyaret etmiş ve Atatürk'e ve onun en büyük eseri Türkiye Cumhuriyeti'ne kelimenin tam anlamiyla hayran kaldığını verdiği demeçlerinde sıkça dile getirmiştir. 1 Kasım 1933 tarihli telgrafında Atatürk, Herriot'a ve Fransız Radikal Partisi üyelerine Türkiye lehine verdiği demeçlerinden dolayı teşekkür eder. Aynı şekilde, 12 Aralık 1933 tarihli mektubunda Atatürk samimi dostluğundan bir an bile kuşku duymadığı Herriot'un Türkiye hakkında yaptığı Türk-Fransız dostluğunu sağlamlaştıracak konferanslardan dolayı ne kadar mutlu olduğunu dile getirir. Herriot, 22 Aralık 1933 tarihli mektubunda, Paris halkına Türkler ve Ulu Önderleri hakkında düşündüklerini dile getirmekten mutluluk duyduğunu ve eylemlerine Fransa'nın diğer bölgelerinde de devam edeceğini bildirir. Fransa Cumhurbaşkanı Albert Lebrun, Cumhuriyet'in kuruluşunun 10'uncu yıl dönümü dolayısıyla Paris'teki Türk Konsolosluğu'nda düzenlenen törene katılmış ve 10 Kasım 1938'de yasa boğulan Türkiye'ye saygılarını sunarak Atatürk hakkında tarihe geçecek şu sözleri sarfetmiştir: "Akıllı ve barış̧̧ı yöntemlerle gerçekleştirdiği eseri halkların tarihinde iz bırakacaktır" (Şimşir, 1981, s.272).

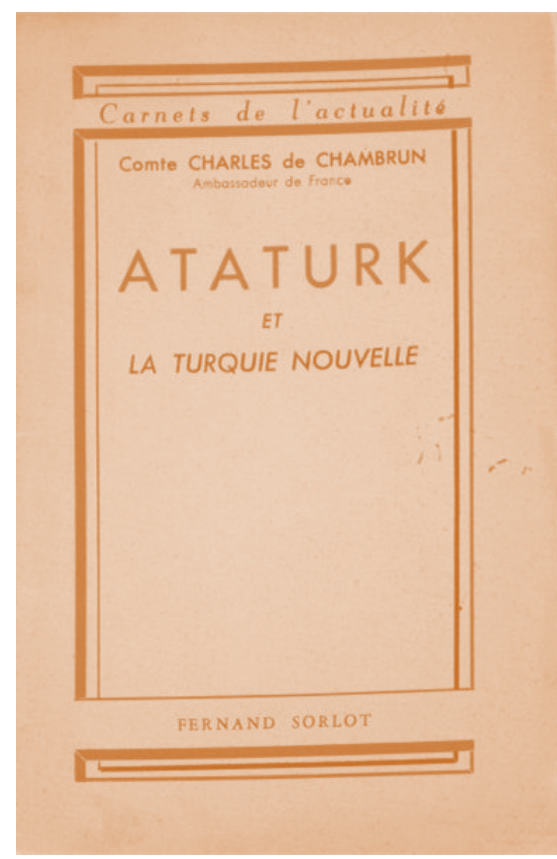

Anadolu'da gerçekleşen Avrupalıların tüm öngörülerini altüst eden siyasi devrime, Fransa'nın Ankara Büyükelçisi olarak beş yıl (1928-1933 yılları arasında) tanıklık etmiş Fransız yazar ve diplomat Charles de Chambrun (1875-1952), Atatürk et la Turquie Nouvelle (Atatürk ve Yeni Türkiye, 1939) adlı yapıtında, Sevr Antlaşmasıyla kaderine boyun eğmiş, bir nevi ölüm fermanını imzalayan Osmanlı hanedanının çöküşünü ve olağanüstü bir kişi olarak nitelendirdiği Mustafa Kemal Paşa sayesinde Türk Ulusunun yeniden doğuşunu anlatır. 27 Eylül 1928'de Mustafa Kemal ile ilk kez karşılaştığında heyecanlı olduğunu dile getiren Charles de Chambrun, ilk izlenimleri şu şekilde olmuştur: “Tüm sorumlulukları alacak oldukça geniş omuzları vardı. Gençlik onu sinsice terk etmişti, yüzünde beliren birkaç hafif kırışıklıklar geçmişin zorlu mücadelelerini yansitiyordu" (Chambrun, 1939, ss.29-31) Türk Devrimi'nin olağanüstü bir adamın, Mustafa Kemal Paşa'nın eseri olduğunu söyleyen Chambrun, ona olan hayranlığını şu sözlerle ifade etmiştir: “Mustafa Kemal, Yeni Türkiye'yi hem tasarlayan beyne hem 
de yaratan güce sahipti. Bu sebepledir ki Yeni Türkiye'nin yaratıcısı, kurtarıcı kılıcı ve dâhi reformcusu olmuştur" (Chambrun, 1981, s.125). Aynı zamanda yapıtında Türk-Fransız dostluğunun tanıklarına da yer veren Charles de Chambrun, Mustafa Kemal ile Fransız Generali Gouraud arasındaki görüşmeden bahseder. Çanakkale Savaşı sırasında bir kolunu kaybeden Gouraud, savaşta hayatlarını kaybedenlerin anısına dikilen anıtın açılma töreninden bir gün önce 1930 yılında Atatürk'ü ziyaret etmiş ve Ankara'da Atatürk'ün bir dostu olarak misafir edilmiştir. “Atatürk'ün, kahramanlığın simgeleştirdiği, General Gouraud'nun boş ceket kolunu heyecanla bana göstererek, bana doğru eğildiğini ve alçak sesle: 'Türk topraklarında yatan onun şerefli kolu, memleketlerimiz arasında son derece değerli bir bağdır' dediğini her zaman anımsayacağım” (Chambrun, 1939, ss.36-37) diyen Charles de Chambrun, ona görüşmede eşlik eden Türk askerlerinin de gözlerinin yaşlarla dolduğunu söyler. Başka bir karşılaşmalarında Chambrun, Atatürk'e İskender'in doğum yerinin de Selanik civarı olduğunu ima etmiş ve anında şu cevabı almıştır: "Karşılaştırma burada sona ersin. İskender dünyayı fethetmişti. Ben fethetmedim. O dünyayı istilâ edeyim derken kendi vatanını unuttu, ben vatanımı asla unutmayacağım" (Chambrun, 1981, s.125) Yunanistan eski başbakanlarından Elefterios Venizelos, Mustafa Kemal ile yaptığı son görüşmesinin ardından Chambrun'e Mustafa Kemal hakkında "çok büyük bir adam, böylesine yüksek zekâya ve devlet bilgisine sahip bir generalle asla karşılaşmadım" (Chambrun, 1939) demiştir. En son görüşmelerinde Mustafa Kemal, kendisinin elini dostça sıkarak: “Türkiye'nin dostu olarak kalınız, ben her zaman sizin dostunuz olacağım” (Chambrun, 1939, s.41) dediğini aktaran Chambrun'e göre Mustafa Kemal, tahta çıkabilecekken, her geçen gün katlanarak artan bilgeliği sayesinde milletin babası, Atatürk olmayı tercih etmiş, nice başarılara imzasını atmasına rağmen kibir ve gösterişten uzak durmuş bir liderdir. 11 Kasım 1938'de Le figaro gazetesinde Mustafa Kemal'in ölümü üzerine kaleme aldığı yazısında Chambrun, “Gazi lafı uzatmayı severdi; çünkü karşısındakini ikna etmek isterdi. Görüşlerinde idealist olup, düşlerinin koyduğu sınırların dışına çıkmasına müsaade etmezdi. Karakterinin en dikkat çekici özelliği de bu değil miydi? Özlemlerini frenlemeyi bilirdi" demiştir.

Fransız devlet adamı, tarihçi ve gazeteci Jacques Benoist-Méchin'in (1901-1983) kaleminden çıkan Mustapha Kemal, la mort d'un Empire (Mustafa Kemal, Bir Imparatorluğun Ölümü, 1954), yazarın Türk milletine ve onun Mustafa Kemal önderliğinde gerçekleştirdiği Kurtuluş Mücadelesine karş1 duyduğu hayranlığın simgesidir. "Dışarıda budanmış, içeride kangren olmuş ülkeye sonradan gelen insanlarla dolup taşan ve borçlarının ağırlığı ile çatırdayan Osmanlı İmparatorluğu" (Benoist-Méchin, 1999, s.61) tükenmiş, kendini savunma ve koruma yetisini kaybetmiş, artık gerçekten yaşayan bir cesetten ibaretti. Uçurumun kenarında ümitsizce celladını bekleyen ülkenin kurtuluşu Anafartalar kahramanı ile gerçekleşecekti. Ülkeyi düşman pençesinden kurtarmak için Mustafa Kemal öncülüğünde birleşen Millî direnişin ayak sesleri Anadolu'nun dört bir yanında duyulmaktaydı. "Her yerde başarı Kemalistlerin gayretlerini taçlandırıyordu ve bu şimşek gibi başarılar da onlara dayanılmaz bir atılım gücü veriyordu" (Benoist-Méchin, 1999, s.200). Anadolu toprakları düşman kuvvetlerinden hızlı bir şekilde temizlenmiş; geçmişte yaşanılanların tekrarlanmaması için yapılan devrimler zincirlemesi ile sağlam sınırlarla çevrili, çağdaş ve bağımsız bir millet yeniden doğmuştur: Tarihte eşi benzeri görülmemiş bu eser Mustafa Kemal'in 
“(...) gücünün ve iradesinin eseri” (Benoist-Méchin, 1999, s.228) olduğu kadar “(..) bu eşi görülmemiş macerada, önünde saygıyla eğilinmezse saygısızlık edilmiş olunacak bir başka baş aktör daha vardır: Türk Halkı. Onun, Mustafa Kemal ile karşılaşmasından çağdaş Türkiye doğmuştur" (Benoist-Méchin, 1999, ss.323-324).

\section{MİLLî MÜCADELE VE CUMHURIYYET DÖNEMİ FRANSIZ TANIKLIKLARIN KOLEKTIF HAFIZANIN OLUŞUMUNA KATKISI}

Birinci Dünya Savaşı'ndan galip ancak yorgun çıkan Fransa, savaşın yaralarını sarmak için kendi iç meselelerine dikkat kesilmiş, yaşanılanların sorumlusu olarak Almanya'yı görmüştür. Fransız basını da sosyal ve ekonomik problemlerle boğuşan Fransa üzerine yoğunlaşmış, Türk kurtuluş mücadelesine fazla ilgi duymamışlardır. Gerek Haçlı Seferleri ile başlayan dinî-politik nedenlerden gerekse de XVI. yüzyıldan beri Fransız yazınında yer alan önyargılı düşüncelerden dolayı Fransızlarda zaten var olan olumsuz Türk imgesi, Türklerin Balkan ve Birinci Dünya Savaşlarında da Fransızların karşısında yer almasıyla had safhaya ulaşır. Anadolu ve Trakya üzerinde siyasi çıkarları olan Yunanlıların ve Ermenilerin basın yayın organları aracılığıyla yürüttükleri propagandalar da işin içine dâhil olunca Fransız kamuoyunda Türklere karşı önlenemez bir önyargı oluşmuştur. Neyse ki Ankara Anlaşmasından sonra Türkiye Paris'te bir temsilciliğe kavuşunca, Fransız kamuoyunda kendini savunma çalışmalarında bulunmuştur. Ancak Türklerin lehine Fransız kamuoyunu aydınlatma konusunda asıl etkili çaba yine Türklere karşı yapılan haksızlıklara isyan eden Türk dostu Fransız yazarlar, gazeteler ve gazeteciler aracılığıyla gerçekleşmiştir. Anadolu'daki millî hareketlenmelerin gittikçe güçlenerek artması ki bunun en güzel örneklerinden biri de 9 Eylül 1922'de İzmir'de Yunanlıların denize dökülüşü ile taçlanan Türk Zaferi, Fransız kamuoyunda da büyük yankı uyandırmış, “adaletin” zaferi olarak görülmüştür (bkz. Akyüz, 1975). Bundan sonra Mustafa Kemal önderliğinde Anadolu'da kurulan Millî Direniş başarılarına her geçen gün başarı katmaya devam etmiş, Türk Ulusunun amacının yalnızca bağımsızlık mücadelesi olduğunu Fransız basını kabul etmeye başlamıştır.

Anlattığı anılarla, öykülerle her fırsatta Türkleri ne kadar çok sevdiğini ve takdir ettiğini söyleyen, kendisini “yarı Türk" (Farrère, 1973, 220) ve "Türklerin dostu” (Farrère, 1973, 221) olarak nitelendiren Fransız subay Claude Farrère (1876-1957), Türklerin Manevi Gücü (Forces Spirituelles de l'Orient, 1937) adlı yapıtında, her ne kadar Fransız halkının coğrafya bakımından tam bir cehalet içinde olduğunu, bu nedenle bu çabasının çok kolay olmayacağını dile getirse de Türkleri neden sevdiğini, Türklerin düşmanlarını neden sevmediğini ve Türkiye'nin bozgununun gerçekte Fransızların menfaatleriyle nasıl ters düştüğünü anlatmayı dener (bkz. Farrère, 1973, 11). 1913 yılında l'Instransigeant gazetesinde yayınladığı, “(...) Hazırlanan bu kavgada ben, kuvvetliye karşı zayıfın, zalime karşı mazlumun, Hristiyan'a karşı Müslümanın tarafında" (Farrère, 1973, s.12) olduğunu vurguladığı ve Birinci Dünya Savaşını öngören makalesiyle Farrère, Avrupa basınında eleştiri oklarının hedefi haline gelir. Buna rağmen sonrasında yaşananların da doğrulayacağı gibi düşüncelerinde haklı olduğunu sağduyusu güçlü insanlara anlatmak için yazdığı yapıtında Türkleri sevmesinin maddi ve manevi iki sebebi olduğunu ayrıntılı olarak açıklar. Maddi sebebini, Birinci Dünya Savaşına göndermede bulunarak Türklerle karşı cephede savaşmalarına rağmen asıl 
darbenin Fransız-Rus ittifakından kaynaklandığını belirtir. Rusya'nın Fransa'yı kendi çıkarları doğrultusunda nasıl kullandığını, Yunanlıların ve Bulgarların ise katliamlarından ve Fransa'nın büyümesine nasıl engel olduklarından bahsederek Türklerle iş birliği yapmanın Fransa'nın menfaatine olduğunu vurgular. Manevi sebebini ise 1902-1904 ve 1911-1913 yılları arasında Doğu'ya yaptığı yolculuklardan edindiği deneyimler aracılığıyla açıklar. Yolculuğun başında çoğu Fransız gibi Türklere karşı ön yargılı olduğunu itiraf eden Farrère, Türklerle vakit geçiren birçok Fransız subayı gibi tamamen Türk dostu olarak vatanına döndüğünü belirtir. Türklerin yegâne amacının yalnızca kendi topraklarını korumak olduğunun altını çizen Farrère, bu konuda Türkleri takdir ettiğini de yazmaktan çekinmez: “Ve eğer Fransız olmasaydım, Yunanistan’a karşı, İngiltere'ye karşı, hemen hemen bütün Avrupa'ya karşı Ankaralı dostum Kemal Paşa'nın yanında öyle candan savaşırdım ki! (...) Türk, namusludur, vefakârdır, dürüsttür; katı bir görünüşü vardır belki. Ama zayıflara ve iyilere karşı inanılmayacak kadar yumuşacıktır" (Farrère, 1973, ss.21-22).

Türkler hakkında olumlu görüşlerinin yanı sıra, çoğu yabancı yazar ve basın gibi Farrère, Millî Mücadeleyi eleştirmiş Devrim hareketlerinin "İslam'ı ortadan kaldırmak" ve "Türk milletini kökünden koparmak" (Farrère, 1973, s.203) için yapıldı̆̆ını dile getirmiştir: “Türkiye, ananeleriyle, idealiyle, faziletleriyle, örf ve adetleriyle, Osmanlı Türklerinin Türkiye'sidir. O Türkiye'nin de mükemmel bir bütün olduğunu söylemiyorum. Ama hiç olmazsa mükemmelleşmeye elverişli bir bütün olduğu muhakkak. Yeni Türkiye ise, bu temeli bir tarafa bırakıp, her şeyi bir tarafa atıp, işe en aşağıdan, sıfırdan başlıyor. Çok zor iş bana kalırsa. Hatta insanüstü de diyebilirim" (Farrère, 1973, ss.203-204).

Turgut Özakman'ın deyişiyle, “Millî Mücadele işte bu mucizenin, bu onurlu, güzel çılgınlığın adıydı." (Özakman, 2006, s.20) "Bölünmez, bağımsız, hür ve çağdaş bir Türkiye” (Özakman, 2006, s.21) için yola koyulan başta Mustafa Kemal Atatürk olmak üzere Millî Mücadele kahramanları, Farrère gibi aksini düşünen herkesi yanıltmış, tarih boyunca nice başarılara imza atmış Türk milleti bir kez daha kurtuluş mücadelesinde imkânsızı başarmıştır. Boğazı, özellikle de mimarisi ile İstanbul'a büyük bir hayranlık besleyen Farrère, İstanbul yerine "memleketin en verimsiz, en yaşanmaz yeri" (Farrère, 1973, s.216) olarak nitelendirdiği Ankara'nın başkent olarak seçilmiş olmasını eleştirirken, TBMM binasının da estetikten yoksun "korkunç derecede çirkin" (Farrère, 1973, s.218) olduğunu söyler. Ankara'da yaşayanların da Batı kültürünü her alanda kopya etmeye çalıştıklarından içlerindeki millî şuuru yitirme tehlikesinde olduklarını dile getirir: “Gerçekte, üzerinde yaşadığımız şu dünyanın en asil insanları olan Türkler, dört yüz yıl boyunca dostumuz olan ve gönüllerinde hâlâ dostumuz kalmış olan; yaşamaya ve büyümeye susamış olan Türkler... Belki takip edilecek yolda yanılıyorlar... Ama iyi niyetle yanılanlar, şerefle yanılmış olur..." (Farrère, 1973, s.230)

Nitekim şerefle yanılan kendisi olmuştur: 19 Haziran 1922'de Büyük Taarruz öncesi Atatürk ile İzmit'te görüşmüş, Atatürk, büyük bir misafirperverlik örneği sergileyerek yazarı kabul etmiş ve şerefine verdiği çay ziyafetinde Türk ordusunun Osmanlı Devleti'nin küllerinden bağımsız bir devlet yaratma aşamasında ne denli ilerlediğini anlatmıştır. Yeni bir millî uyanış içerisinde olan Atatürk'ün önderliğinde Türk Halkının, bağımsızlık aşkı ile kuşanmış ve millî kültür ile bezenmiş çağdaş bir toplum olma yolunda sağlam adımlarla ilerlediğini görmüştür. 


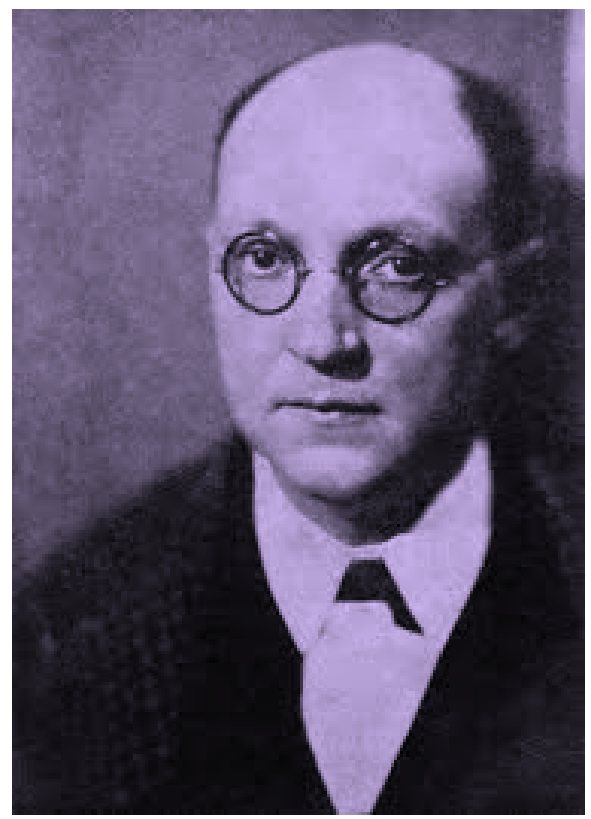

Georges Duhamel

İlk kez 1924 yılında İzmir'i ve İstanbul'u ziyaret eden Fransız Akademi üyesi, şair ve yazar Georges Duhamel (18841966) yeni bir düzen kurma aşamasında olan Türkiye'ye tanıklık etmiştir. 1954 yılında ülkemize tekrar gelen ve iki haftadan fazla bir süre ülkemizde kalan Duhamel, Cumhuriyet'in ilanından itibaren Türkiye'nin geçirdiği evrim karşısında büyük bir hayranlık duymuş ve kendi gözlem, inceleme ve araştırmalarını La Turquie, nouvelle puissance d'Occident (Yeni Türkiye: Bir Batı Devleti, 1954) adlı yapıtında bir arada sunmuştur. "Bir zamanlar Orta Çağ karanlıkları içinde yaşarken altın çağına girmiş olan" (Duhamel, 1998, s.66) Türkiye, gücü geçmişe yüzü geleceğe dönük olarak, dünya ulusları arasında hak ettiği yeri kazanabilmek için onca mücadele vermiş, “(...) aşağı yukarı bir yüzyıldır gelişmiş diye adlandırılan ulusların benimsediği bilimsel, sosyal ve moral bir uygarlık çeşidine bütün gücüyle katılmayı amaç edinmiştir. Türkiye çekinmeden, duraklamadan Medeni Kanun'u, laik devlet düzenini, Latin alfabesini ve bir aydın takımı yetiştirebilmek için gerekli eğitim sistemlerini kabul etmiştir. Otuz yıl içinde elde edilen sonuçlar en iyimser olanları bile şaşırtacak niteliktedir" (Duhamel, 1998, s.8). Türkiye ile Fransa arasında 17 Haziran 1952 tarihinde Ankara'da imzalanan Kültür Anlaşması'na da değinen Duhamel, iki ülke arasında fotoğraf, heykel kalıpları, kitap, belge, arşiv değiş tokuşunu kolaylaştırıcı maddeleri içine alan bu anlaşmanın, kültür birliğinin sağlanması ve iki ulusun birbirini daha yakından tanıması için önemli bir adım olduğunu vurgular. Türk-Fransız dostluğunun Fransızların siyasi çıkarlar bakımından da önemin taşıdığını söyleyen daha önce sözünü ettiğimiz Fransız yazarlarla birleşen Duhamel,

\footnotetext{
“Bugün de söylüyorum: Türkiye'nin dostluğunu kaybedersek Ortadoğu'da kalan son kalelerimiz de çökecektir. Türkiye uzun tarihinin o can alıcı dönemini yaşamakta, Batı uluslarının gidişini desteklemek için elinden geleni yapmaktadır. Bu büyük emek, sonsuz cesaret isteyen bir iştir (...) Belki de bir gün bu ulus, dünya yüzündeki insan topluluklarının denge içinde, uygarlık içinde yaşamasına elverişli bir Avrupa, hatta Atlantik uygarlığının kurulmasında, sırası gelince, bize yardım edecektir" (Duhamel, 1998, ss.91-92)
}

diyerek, Fransızların Yeni Türkiye ile dostluk ve kültürel bağları güçlendirmek için verdiği sözleri tutması gerektiğini salık verir. Benzer şekilde, 5 Nisan 1954 tarihinde Cumhuriyet Gazetesinde yayımlanan yazısında, Fransız kültüründeki felsefi görüşlerinin ve efsanelerin dayandığı unsurlardan çoğunun Türkiye'de derin kökleri olduğunu ve Türk milletinin dünyadaki bütün milletler arasında gerek etnik tipleri gerek düşünce tarzları gerekse hadiselere karşı tepkileri bakımından Fransızlara en fazla benzeyen millet olduğunu dile getirmiştir (Duhamel, 1998, ss.9192). Bu sebepledir ki “(...) Batılı milletlerin en doğulusu olarak” (Duhamel, 1998, s.99) nitelendirdiği Yeni Türkiye’yi anlamak ve anlatmak istemiş, onu ülkesine daha iyi tanıtmak için elinden geleni yapmaya çalışmıştır. 
İsviçreli-Fransız gazeteci ve yazar Paul Gentizon (1885-1955), Temps gazetesi adına 1922-1928 yılları arasında Türkiye'de bulunmuş, çöken Osmanlı İmparatorluğu'nun kalıntılarından kurtulup yüzünü Batı uygarlığına dönmüş Yeni Türkiye'ye tanıklık etmiş ve gözlemlerini Mustapha Kemal ou l'Orient en Marche (Mustafa Kemal ve Uyanan Doğu, 1929) adlı yapitında anlatmıştır. Mustafa Kemal'i düşünceleri ve gerçekleştirdiği devrimleriyle yalnızca Türkiye'nin değil, bütün Doğu'nun öncüsü olarak nitelendiren yazar, etnik yönden olmasa da politik, coğrafi, ekonomik, kültürel ve moral yönünden bir birliğe dayanan bir millet olma amacı güden "Türkiye'nin bütünleşmesinden güç ve güven, yurttaşlık ateşinden ise büyüklük doğacaktır" (Gentizon, 2001, s.82) demiş ve çağdaş anlamda milliyet fikrinin Doğuda büyük yankılar uyandıracağını savunmuştur. Yazar, Mustafa Kemal'in öncülüğünde gerçekleştirilen devrimlerin dünya tarihindeki damgasını vuran öteki devrimlerle karşılaştırırken, ulaşılan sonuçlar bakımından Türk devrimlerinin üstünlügünü şu şekilde özetler:

“Fransız İhtilali, siyasi kurumlar alanında olmak üzere sınırlı kalmıştır. Rus İhtilali, sosyal alanları sarsmıştır. Sadece ve sadece Türk İhtilalidir ki siyasi kurumlara, sosyal ilişkilere, dine, aileye, ekonomik hayat geleneklerine, hatta toplumun moral temellerine hücum etmiştir. Bir değişim yeni bir değişime neden olmuştur. Bir reform bir ötekine şartlar oluşturmuştur. Çünkü bunların hepsi halkın hayatında yer tutmuştur" (Gentizon, 2001, s.164).

Fransız Anayasa Hukuku ve Siyaset Bilimi uzmanı Prof. Dr. Maurice Duverger (1917-2014) 27 Mayıs 1961'de Le Monde gazetesinde yayımlanan yazısında, Mustafa Kemal'in eserinin, İkinci Dünya Savaşı'na kadar, Türkiye çerçevesinde takdir edilip, arkaik bir ülkenin modern ulusa dönüş çabasının hayranlıkla karşılandığını belirterek; 1945'den itibaren de Kemalizm'in artık yalnızca Türk tarihinde bir an olmadığını siyasi bir sistem şekline dönüştüğünü dile getirir. Cumhuriyetçi ve özgürlükçü ideolojiye sahip Cumhuriyet Halk Fırkası partisinin komünist ve faşist partilerden son derece farklı olduğunu savunur. Tek bir partiye dayalı olduğundan ve çekişmeli seçimler olmadığı için Kemalist rejimin o yıllarda demokratik olmadığını ancak yapısal açıdan da totaliterlikle hiçbir ilgisinin bulunmadığını söyleyen Duverger, birçok partinin adil ve özgür seçimlerde yarışmasının Mustafa Kemal'in bir an önce gerçekleştirmek istediği ideali olduğunu belirtir (Duverger, 1961).

Millî Mücadele günlerine tanıklık etmiş Fransız gazeteci-yazar Berthe Georges Gaulis (18701950), ulusal direnişin ruhunu bizzat yerinde gözlemleyerek, izlenimlerini, yazdığı kitaplar ya da Fransız gazetelerinde yayımlanan makaleleri aracılı̆̆ıla tüm dünya ile paylaşmış; benliğini koruyarak çağdaş bir millet olma yolunda ilerleyen Türk Milleti'nin tarafında yer aldığını göstermiştir. Millî mücadele için “(...) bu istiklal savaşıydı; yuvada ne kaldıysa, işte onu kurtarma savaşı idi" (Gaulis, 2006, s.49) diyen Gaulis, Mustafa Kemal'in "Askeri kumanda üstünlüğ̈̈ ve sivil düzen getirme yeteneği" (Gaulis, 2006, s.33) sayesinde başarılı bir yol çizdiğini belirtir. Çankaya'da misafir edildiği sıralarda "Türkleri coşturan yeni düşüncenin, millî düşüncenin simgesi" (Gaulis, 1921, s.56) olarak nitelendirdiği Mustafa Kemal ve Millî Mücadele ruhunu paylaşan aydınlarla birçok kez görüşen Gaulis, dışarıdan tarafsız bir gözlemci gözüyle Anadolu'daki gerçeği gözler önüne sermeye çalışmıştır. Millî Mücadele'nin gerekliliğini sonuna kadar savunan Mustafa Kemal B. Gaulis'e, “Şayet, bütün bu sözlerden sonra, sizleri bir gerçek ya da bir anlayış üzerinde 
aydınlatabildimse, kendimi mutlu sayacağım. Size ifade etmeye çalıştığım o hakikat, şudur: Millet, ışığı görmeye başlamıştır. Bu, onun mutluluk güneşidir. Onu geri çevirecek hiçbir kuvvet değildir" (Gaulis, 2006, s.63) demiştir. Türk- Fransız dostluğunun oluşumunda bir nevi köprü işlevi gören Gaulis, Çankaya'dan ayrılışının şerefine düzenlenen akşam yemeğinde gördüğü manzara karşısında büyülenmiş ve Türk Milleti'nin çağdaşlaşma yolunda ne kadar ilerlediğini şu satırlarla anlatmıştır: “(...) kendine çizdiği yolda, gelenekçiliğini asla bozmaksızın, gücünü geçmişinden alan bir Doğuydu. Onunla bizim aramızda, sıkı bir anlaşabilme hissi vardı. Bu süratli uyanışını, kısmen bize borçlu değil miydi? Fikrî yönde o, bizim tarafımızdan oluşturulmuştu. Fakat yine o, öylesine bir açlım gösteriyordu ki, yakında bizi geçerdi" (Gaulis, 2006, s.66). Millî fikri ölesiye benimsemiş Türk milletinin başarısıyla gurur duyan Gaulis, kendi milletinde de benzer duygular göremediği için üzüntüsünü şu şekilde dile getirir: "Bu hayatiyeti, engelleri aşan bu hızı, bu savaşmayı, başkalarının amacı uğruna acı çekmeyi anlamaktan, biz bir hayli uzaktık. Bu özveriler bolluğunu, fedakârlığın böylesine coşmasını, bizler ne çabuk unutmuştuk?" (Gaulis, 2006, s.66) Fransız basınında çıkan yazılarında, Türklerin Vatan savunması uğruna ölümü göze alarak kahramanca verdikleri mücadeleleri içten ve samimi duygularla anlatmış ve bu cesur davranışından dolayı Büyük Millet Meclisi kendisine bir teşekkür mektubu göndermiştir (Gaulis, 1981, s.16). Atatürk'ün de sıkça dile getirdiği gibi, “Biz, millî hudutlarımız içinde istiklalimizden başka bir şey istemiyoruz. Avrupa'dan beklediğimiz, diğer milletlerin hakkını nasıl tanıdıysa, bizim hakkımızı da öyle tanımasıdır. Biz, barıştan başka bir şey istemiyoruz" (Gaulis, 2006, s.113). İşte bu yüce duyguya canı gönülden inanan Gaulis, daha Millî Mücadele zaferle sonuçlanmadan yazdığı Le Nationalisme Turc (Türk Milliyetçiliği, 1921) yapıtını şu cümlelerle sonlandırır: “Türk Millı̂ Harekâtı düşmanı mutlaka yenecektir. Çünkü o harekât yüksek bir ideale dayanıyor; çünkü bu harekâtı yönetenler kendi şahsi çıkarlarını unutmuşlardır; çünkü onlarda büyük bir ruh ve iman var..." (Gaulis, 1981, s.155). Gaulis öngörüsünde haklı çıkmıştır: Bağımsızlık uğruna şahadet şerbetini içen Türk Milleti, kanlarıyla bezenmiş laik ve demokratik Türkiye Cumhuriyeti'nin temelini atmıştır.

\section{SONUÇ}

Hatırlamak ve unutmak bireysel olduğu kadar toplumsal bir süreçtir. Unutmaya, izlerin silinmesine karşı geçmişi canlı tutmak yalnızca tarihçilerin sorumluluğunda görülmemesi, tarih dışı disiplinlerin de tarihçilerin omuzlarına yüklenmiş bu sorumluluğu paylaşması gerektiği düşüncesinden hareketle, çalışmada, Millî Mücadele ve Cumhuriyet Dönemi Fransız tanıklıklarını karşılaştırıp, buluştukları ve ayrıldıkları noktaları saptayarak kolektif hafızanın korunmasına katkı sağlanmaya çalışılmıştır. Bahsedilen dönemde Fransızların Atatürk ya da Türkiye ile ilgili olumlu ya da olumsuz görüşleri bir arada sunularak onların destekleri, korkuları, yanılgıları, övgüleri, yergileri hem Fransız hem de Türk Toplumuna anımsatmayı çalışılmıştır.

Avrupa'nın cenazesini kaldırmaya hazırlandığı millet, tüm imkânsızlıklara ve engellemelere rağmen bağımsızlık mücadelesi vermiş; Mustafa Kemal Atatürk ve silah ve fikir arkadaşlarının önderliğinde millî ruhu benimseyen bütün Anadolu halkının altına imzasını attığı Diriliş Destanı, yalnızca Türk Milleti'nin gururla gelecek nesillere aktaracağı bir eser olmakla kalmayıp aynı 
zamanda tüm dünyanın hayretler içerisinde izlediği ve hayran kaldığı tarihî mücadelenin adıdır. Atatürk'ün fikir dünyasını etkileyen Fransız düşünür ve yazarların gerekse de Yeni Türkiye'nin oluşumuna ve gelişimine bizzat tanıklık etmiş Fransızların, Yeni Türkiye ile inşa edilen kolektif hafızanın oluşumunda nasıl etkin rol oynadıklarını örneklerle göstererek, yedekte bekleyen unutuşa engel olmaya amaçlanan bu çalışma ile Atatürk'ün Fransız Diline hâkim olması onun entelektüel ve devrimci kişiliğinin oluşumuna ve Türk-Fransız dostluğunun gelişimine nasıl katkı sağladığı gösterilmeye çalışılmıştır. Bu nedenle, Mustafa Kemal Atatürk ile Batı arasında köprü işlevi gören Fransızcanın yabancı dil olarak öğretilmesinin şimdiki ve gelecek nesiller için önemini vurgulanmıştır. Aynı zamanda Türk Tarihi'nin en sancılı günlerinin yaşandığı bir dönemde Türkiye'ye gelen Fransız devlet adamları, yazarlar ve gazeteciler ile yakın temasta bulunan Atatürk'ün Fransızlar aracılığıyla Batı'nın Türklere bakış açısını nasıl değiştirdiğini örneklerle gözler önüne serilmeye çalışılmıştır.

Sonuç olarak Türkiye'nin sıkıntılı dönemlerinde bizzat Türkiye'ye gelip kendi gözlem, inceleme ve araştırmalarına dayanarak kaleme aldığı eserlerle, Yeni Türkiye'nin verdiği bu mücadeleyi içtenlikle destekleyen, gerçekleştirilen sosyal, siyasal, moral ve ekonomik tüm devrimleri yakından takip edip kendi duygu ve düşüncelerini ifade etmekten çekinmeyen milletlerden biri de Fransızlar olmuştur. Bu sebepledir ki günümüz ve gelecek kuşaklar için zengin bir kültür dili olan Fransız dilinin öğrenilmesinin sekteye uğramaması hem uygar Türk toplumu için hem de asırlardır süregelen Türk-Fransız dostluğuna leke düşürmemek için önemlidir.

\section{KAYNAKÇA}

Akay, O. (2005). Atatürk'ün Sofrası (3. Basım). İstanbul: Truva Yayınları

Akyüz, Y. (1975). Türk Kurtuluş Savaşı ve Fransız Kamuoyu 1919-1922 (1. Basım). Ankara: Türk Tarih Kurumu Basimevi.

Atatürk, M. K. (2010). Mektuplarım (1. Basım). İstanbul: Bildik Basın Yayın.

Atatürk, M. K. (2017). Gençler İçin Fotoğraflarla Nutuk (21. Basım). İstanbul: Türkiye İş Bankası Kültür Yayınları.

Baldaş, F. (2011). Kanunların Ruhu Üzerine (1. Basım). İstanbul: Hiperlink.

Benoist-Méchin, J. (1999). Mustafa Kemal Bir İmparatorluğun Ölümü (3. Basım). Ankara: Bilgi Yayınevi.

Chambrun, C. (1939). Atatürk et La Turquie Nouvelle (1. Basım). Paris: Fernand Sorlot

Chambrun, C. (1981). “Un Homme Extraordinaire”. Atatürk Pensées et Témoignages (2. Basım). Ankara: Ajans-Türk Matbaacilık.

Chantitch-Chandan, K.S. (1981). "Le Miracle Turc". Atatürk Pensées et Témoignages, Ankara: Ajans-Türk Matbaacılık.

Connerton, P. (1999). Toplumlar Nasıl Anımsar? (1. Basım). İstanbul: Ayrıntı Yayınları.

Duhamel, G. (1998). Yeni Türkiye: Bir Batı Devleti (1. Basım). İstanbul: Yenigün Haber ajansı

Duverger, M. (1961). “Le Kemalisme”, Le Monde.

Farrère, C. (1930). Turquie Ressuscité (1. Basım). Paris: Editions des Cahiers Libres.

Farrère, C. (1973). Türklerin Manevi Gücü (1. Basım). İstanbul: Tercüman Gazetesi. 
Fouillé, A. (2012). Avrupa Milletlerin Karakter ve Psikolojileri (1.Basım). İstanbul: İdil Yayıncılık.

Gentizon, P. (2001). Mustafa Kemal ve Uyanan Doğu (4. Basım). Ankara: Bilgi Yayınevi.

Georges-Gaulis, B. (1921). Le Nationalisme Turc (1. Basım). Paris: Librairie Plon.

Georges-Gaulis, B. (1981). Kurtuluş Savaşı Sırasında TÜRK MILLİYETÇİLİĞİ (1. Basım). İstanbul:

Radyo Yayınları.

Georges-Gaulis, B. (2006). Çankaya Akşamları (1. Basım). İstanbul: İlgi Kültür Sanat.

Guignes, J. (2018). Hunların Türklerin Moğalların ve Daha Sair Batı Tatarlarının Tarih-i Umûmisi (1.Basım). İstanbul: Ötüken Neşriyat A.Ş.

Gürbüz, D. T. (1983). Atatürk'ün Okuduğu Kitaplar, Özel İşaretleri, Uyarıları ve Düştüğü Notlar ile (1.Basım). Ankara: Türkiye İş Bankası Kültür Yayınları.

Halbwachs, M. (1950). "La Mémoire Collective". http://classiques.uqac.ca/classiques /Halbwachs_maurice/memoire_collective/memoire_collective.pdf Erişim tarihi: 22.01.2019

Halbwachs, M. (2016). Hafızanın Toplumsal Çerçeveleri (1. Basım). Ankara: Heretik Yayınları.

İnan, A. (2000). Atatürk Hakkında Hatıralar ve Belgeler (3. Basım). Ankara: Türkiye İş bankası Kültür Yayınları.

İnan, A. (1999). Düşünceleriyle Atatürk (3. Basım). Ankara: Türk Tarih Kurumu Basımevi.

Kocatürk, U. (1969). Atatürk'ün Fikir ve Düşünceleri (1. Basım). Ankara: Edebiyat yayınevi

Loti, P. (1973). Can Çekişen Türkiye 1914. Tercüman 1001 Temel Eser.

Meslier, J. (2005). Sağduyu Tanrısızlığın İlmihali (7. Basım). İstanbul: Kaynak Yayınları.

Özverim, M. (2007). Mustafa Kemal ve Corinne Lütfü Bir Dostluğun Öyküsü (3. Basım). İstanbul: Doğan Kitapçılık AŞ.

Palenque, M. y Giné, M. (2018). “El Poeta Hispano-Belga Léon van Montenaeken”, Çédille: revista de estudios franceses, 14, 477-507.

Ricoeur, P. (2012). Hafıza, Tarih, Unutuş (1. Basım). İstanbul: Metis Yayınları.

Şimşir, B. N. (1981). "Atatürk et Ses Amis Français". La Turquie et la France à l'époque d'Atatürk. Editör: Dumont, P., Bacqué-Grammont J-L. Paris: Association Pour le Développement Des Études Turques.

Tansu, S. N. (2011). İki Devrin Perde Arkası Teşkilât-1 Mahsusa Başkanı Hüsamettin Ertürk (2.Basım). İstanbul: İlgi Kültür Sanat Yayıncılık.

Tezer, Ş. (2008). Atatürk'ün Hatıra Defteri (6. Basım). Ankara: Türk Tarih Kurumu Yayınları,

Ünsal, A. (1981). "La Bibliothèque politique française d'Atatürk". La Turquie et la France à l'époque d'Atatürk. Editör: Dumont, P., Bacqué-Grammont J-L. Paris: Association pour le développement des études turques. 
TÜRK BILİMKURGU

EDEBIYATI

VE ARKETIPLER

DR. VELİ UĞUR

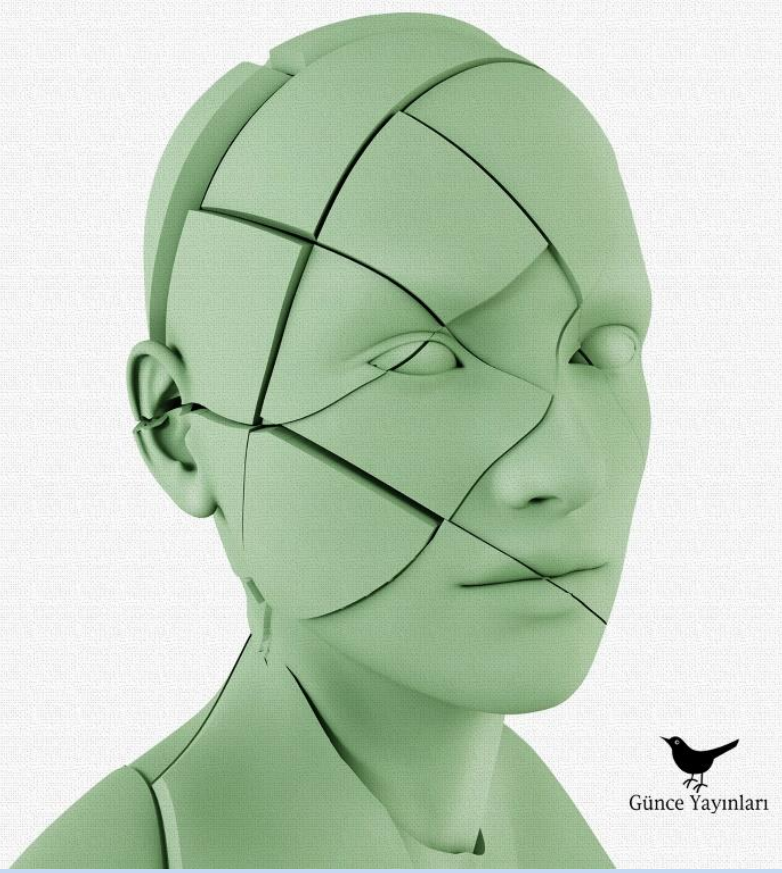

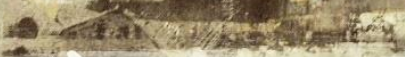

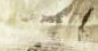

Jktdl| Џill|

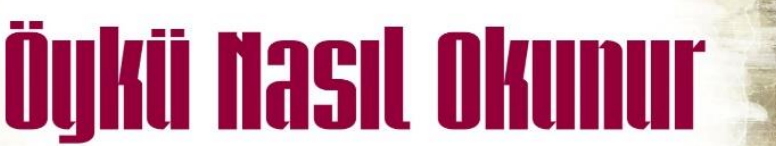

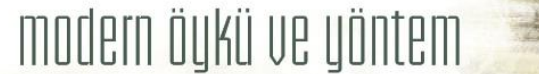

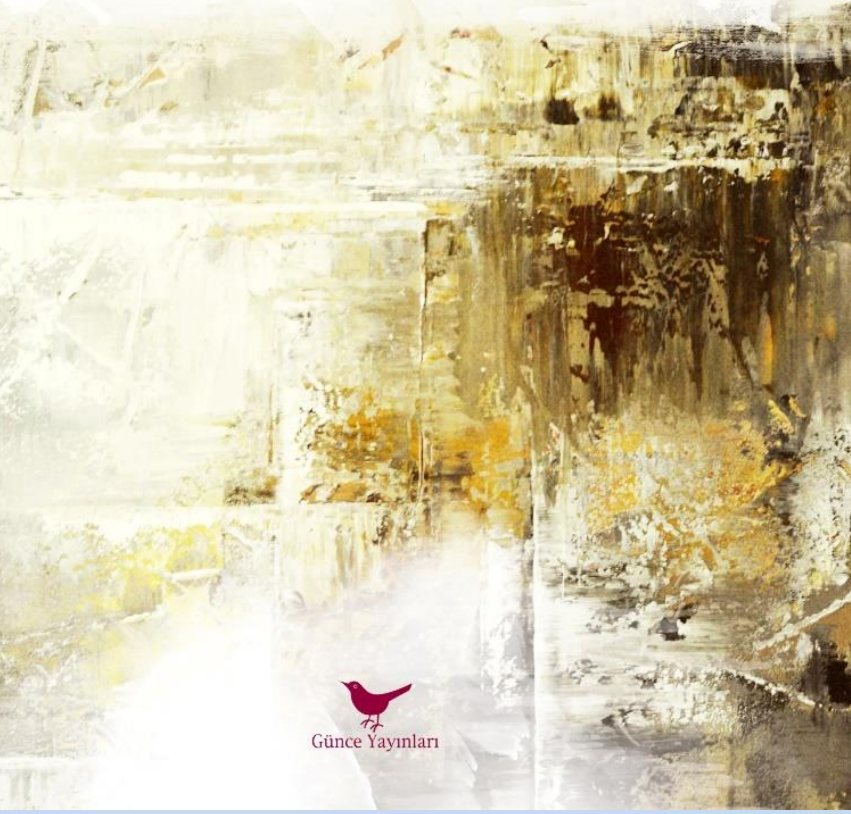

\section{Yazma Sanatı}

Edebivatutn Ebemklusăgu|

Halit Zijya Hilkâyecilliğinde Renklerin Dili

\section{MAKSUT Yit̆̈itBAŞ}

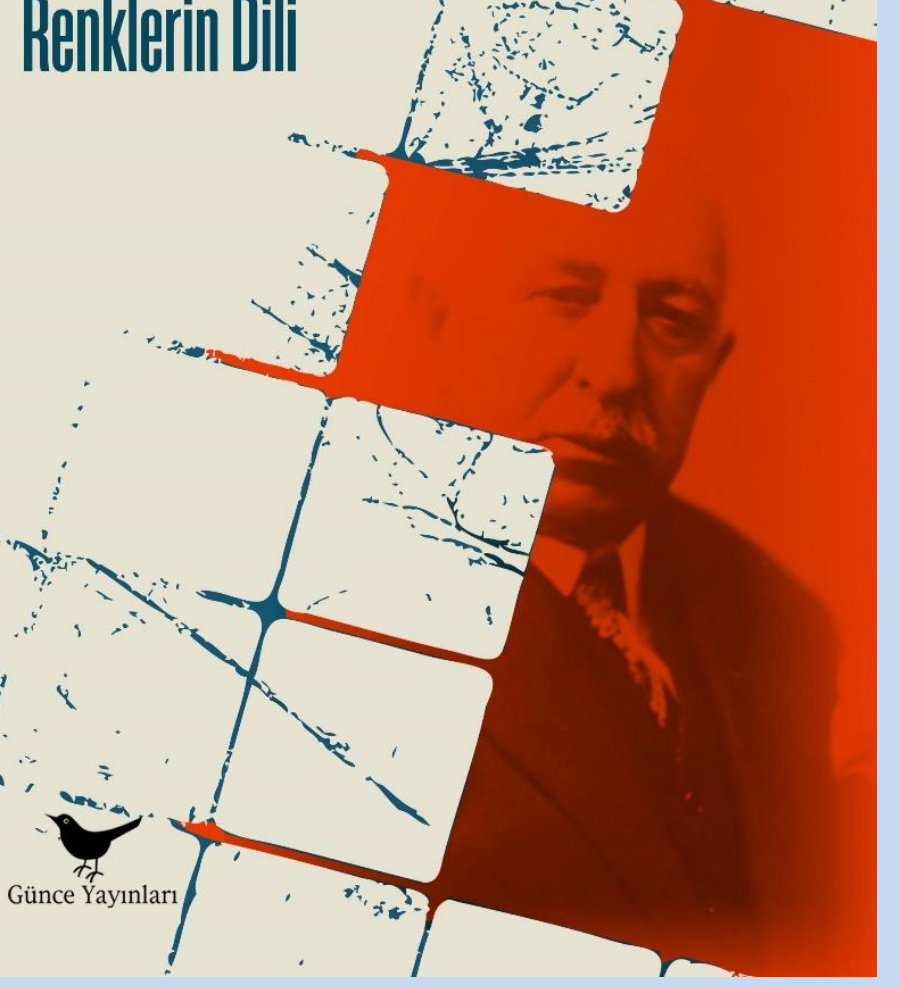

Türkçe Doğru ve Etkili Yazma Teknikleri

Prof. Dr. Önder Göçgün 